PONTIFÍCIA UNIVERSIDADE CATÓLICA DO RIO DE JANEIRO

Produtos agregados da marca Rock in Rio. O que motiva o consumidor a comprar produtos oficiais?

Alberto Medeiros Montanari

Trabalho de Conclusão de Curso

Centro de CIÊnCIAS SOCIAIS - CCS

DEPARTAMENTO DE ADMINISTRAÇÃo Graduação em Administração de Empresas 


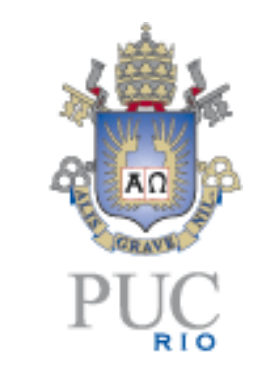

Alberto Medeiros Montanari

\title{
Produtos agregados da marca Rock in Rio. $O$ que motiva o consumidor a comprar produtos oficiais?
}

\author{
Trabalho de Conclusão de Curso
}

Trabalho de Conclusão de Curso, apresentado ao programa de graduação em Administração da PUC-Rio como requisito parcial para a obtenção do titulo de graduação em Administração.

Orientador: Alessandra Baiocchi A. Corrêa 


\section{Agradecimentos}

Aos pais, Zilda Medeiros e Carlos Alberto Montanari, aos avós, Amaury, Lourdes, Aloísio e Célia, ao irmão, Carlos Montanari, e ao Dr. Silas Augusto Martins, por todo o apoio durante essa longa jornada. Aos quatro melhores amigos que estiveram diariamente presentes nessa caminhada, Adam Marcel, Alessandra Lanzilotta, Betina Monnerat e Caroline Koury. Aos excelentes professores e orientadores que me guiaram tanto profissionalmente, como pessoalmente e contribuíram para uma formação mais rica e plena, com especial agradecimento à Alessandra Baiocchi minha orientadora, Andréa Cherman, Claudia Soares, Lea Mara e ao querido Marcus Hemais. 


\section{Resumo}

Montanari, Alberto. Baiocchi, Alessandra. O que motiva o consumidor a comprar os produtos oficiais do Rock in Rio 2015. Rio de Janeiro, 2015.p.32.Trabalho de Conclusão de Curso - Departamento de Administração. Pontifícia Universidade Católica do Rio de Janeiro.

No mercado de entretenimento existem alguns eventos que se tornaram referências globais.Construíram uma marca forte no mercado que são reconhecidas em diversos países. Este é o caso do Rock in Rio, um megaevento que nasceu no Rio de Janeiro. A marca Rock in Rio além do evento musical também vende uma variada gama de produtos oficiais, esses produtos também chamados de licenciados podem ser encontrados em diversas categorias e muitas vezes continuam sendo comercializados após o término do evento. Este trabalho se propõe a investigar a motivação do consumidor ao comprar um produto oficial da marca Rock in Rio. Para atingir aos objetivos pretendidos realizou-se pesquisa bibliográfica, seguida de pesquisa exploratória e qualitativa e de uma terceira fase quantitativa. A pesquisa mostrou que menos da metade das pessoas que foram ao evento comprou algum tipo de produto, levando em consideração o período antes do evento e o período após o evento. Este fato indica que o foco principal dos consumidores entrevistados não estava na compra dos produtos relacionados ao evento, e sim no produto principal comprado por eles, os shows musicais do Rock in Rio.

Palavras- chave

Megaevento. Produto agregado, Motivação de consumo. Entretenimento. Marca. 


\section{Abstract}

Montanari, Alberto. Baiocchi, Alessandra. O que motiva o consumidor a comprar os produtos oficiais do Rock in Rio 2015. Rio de Janeiro, 2015. p.32. Trabalho de Conclusão de Curso - Departamento de Administração. Pontifícia Universidade Católica do Rio de Janeiro.

In entertainment market there are some events that have become global benchmarks. They built a strong brand in the market that are recognized in many countries. This is the case of Rock in Rio, one mega-event that was born in Rio de Janeiro. The Rock in Rio brand beyond music event also sells a wide range of official products, these products also called graduates can be found in various categories and often continue to be marketed after the event. This study aims to investigate the consumer motivation to buy an official product of the Rock in Rio brand. To achieve the intended objectives held literature, followed by exploratory and qualitative research and a third quantitative phase. Research has shown that less than half of the people who were at the event bought some kind of product, taking into consideration the period before the event and the period after the event. This indicates that the main focus of consumers surveyed was not in the purchase of products related to the event, but the main product purchased by them, the concerts of Rock in Rio

Key-words

Consumer. Behavior. Event. Marketing. Motivation. Entertainment. Brand. 


\section{Sumário}

1. O tema e o problema de estudo 1

1.1. Introdução ao tema e ao problema do estudo 1

1.2. Objetivo do estudo 4

1.3. Objetivos intermediários do estudo 4

1.4. Delimitação e foco do estudo 4

1.5. Justificativa e relevância do estudo 4

2. Referencial teórico 6

2.1. A força da marca como diferencial competitivo 6

2.2. Produto Cultural e Marketing Cultural $\quad 7$

2.3. Produtos Oficiais ou Licenciados 10

2.4. Motivação 11

2.4.1. O Processo de Motivação 12

2.4.2. Teorias da Motivação 13

2.4.2.1. Teoria de motivação de Freud 13

2.4.2.2. Teoria da motivação de Maslow 13

2.4.2.3. Teoria da motivação de Herzberg 15

2.5. Comportamento do Consumidor 15

2.5.1. Tipos de consumidores 15

2.5.2. Influências no processo de compra 16

$\begin{array}{ll}\text { 2.5.3. Necessidade } & 19\end{array}$

3 .Métodos e procedimentos de coleta e de análise de dados do estudo 22

3.1. Etapas de coleta de dados 22

3.2. Fontes de informação selecionadas para coleta de dados no estudo e $\begin{array}{ll}\text { amostra } & 23\end{array}$

3.3. Procedimentos e instrumentos de coleta de dados utilizados no estudo 26

3.4. Formas de tratamento e análise dos dados coletados para o estudo 27

3.5. Limitações do Método 
4. Apresentação e análise dos resultados

4.1. Análise das entrevistas em profundidade 29

4.2. Análise do questionário online 30

4.2.1. Frequência e compra do produto 30

4.2.2. Descrição do local de compra 32

4.2.3. Produtos mais procurados 33

4.2.4. Motivação de compra 37

4.2.5. Estímulos e influências no momento da compra 40

5 . Conclusões e recomendações para novos estudos 43

5.1. Sugestões e recomendações para novos estudos 44

6. Referências Bibliográficas 46

Anexo 1 - Roteiro das Entrevistas em Profundidade 55

Anexo 2 - Transcrição das Entrevistas em Profundidade 56

Anexo 3 - Questionário sobre compra de produtos do Rock in Rio. $\quad 65$

\section{Lista de figuras}

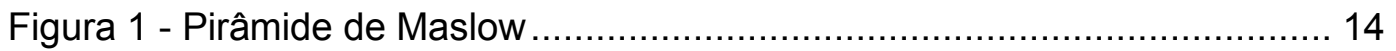

Figura 2 - Fatores de influência no processo de decisão de compra ................ 17

Figura 3 - Modelo de estímulos e resposta................................................... 19

Figura 4 - Relação entre necessidades e desejos, a hierarquia de necessidades, e a três funções básicas de um produto ............................................. 21 


\section{Lista de Tabelas}

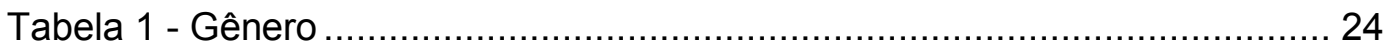

Tabela 2 - Faixa Etária ............................................................................. 24

Tabela 3 - Escolaridade .................................................................... 25

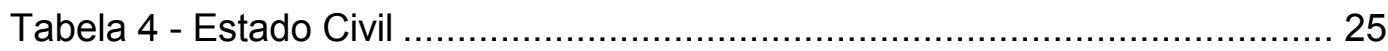

Tabela 5 - Renda Familiar Mensal....................................................... 25

Tabela 6 - Pessoas que foram ao Rock in Rio.............................................. 30

Tabela 7 - Pessoas que foram ao evento e compraram ou não algum produto. 31

Tabela 8 - Pessoas que não foram ao evento e compraram ou não algum

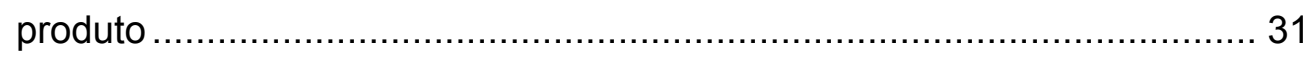

Tabela 9 - Produtos mais comprados ......................................................... 33

Tabela 10 - Produtos que gostariam de ter comprado ..................................... 36

Tabela 11 - Por que comprou o produto do RIR? ..................................... 37

Tabela 12 - Por que você não comprou? ....................................................... 39

\section{Lista de Gráficos}

Gráfico 1 - Local de compra dos produtos do RIR ....................................... 32

Gráfico 2- Porque comprou o produto do RIR? ........................................... 38

Gráfico 3 - Por que não comprou? ......................................................... 39

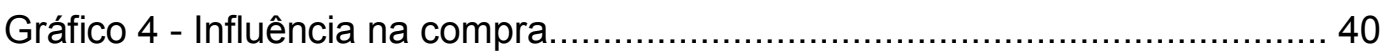

Gráfico 5 - Intenção de compra ............................................................. 41

\section{Lista de Quadros}

Quadro 1 - Perfil dos Entrevistados 


\section{O tema e o problema de estudo}

Este primeiro capítulo contempla a contextualização e definição do problema de pesquisa, o objetivo geral, os objetivos específicos, a justificativa e a estrutura do presente trabalho.

\subsection{Introdução ao tema e ao problema do estudo}

O mercado de entretenimento vende diversão, arte e cultura e engloba diversos segmentos da indústria, como música, teatro, cinema e televisão. Além disso, promove diversos eventos, sendo que os segmentos que tem mais destaque se encontram os espetáculos musicais, teatrais, eventos esportivos e exposições artísticas (SITE DE OLHO NO MERCADO).

O mercado de eventos no Brasil está em expansão e cresce por volta de $14 \%$ ao ano, aumentando a sua participação no PIB do país de $3,1 \%$, em 2001, para 4,32\%, em 2013(Dimensionamento Econômico da Indústria de Eventos 2013, lançado em setembro de 2014, realizado pela Abeoc Brasil, em parceria com o Sebrae), O crescimento médio do mercado de entretenimento no Brasil é elevado comparado aos países da América do Sul. O Brasil consolidou sua posição entre os países que sediam grandes shows nacionais e internacionais, sendo o segundo no ranking do mercado de shows na América Latina, atrás apenas do México, segundo Pricewaterhousecoopers. A expectativa é que o consumo de shows no Brasil cresça 39\% até 2018, de acordo com Gardênia Rogatto, especialista em entretenimento da consultoria PwC Brasil. O mercado de show no país, que em 2013 gerou $R \$ 357$ milhões, pode passar para $R \$ 496$ milhões em 2018 (PwC, 2013).

Entre os festivais de músicas ocorridos no Brasil, o Rock in Rio se destaca. É um festival de música que desde sua primeira edição não se restringiu apenas ao rock. De acordo com o site Correio do Brasil (2015), o evento se consagrou o maior festival de música POP e entretenimento do mundo. Foram produzidas dezesseis edições. Destas, seis ocorreram no Brasil (1985, 1991, 2001, 2011 , 2013 e 2015), seis em Portugal (2004, 2006, 2008, 2010, 2012 e 2014), três na 
Espanha (2008, 2010 e 2012) e uma nos Estados Unidos, também em 2015 (RESENHANDO, 2015).

Segundo Rodolfo Medina, vice-presidente de marketing e comercial do Rock in Rio, em entrevista publicada no site Meio\& Mensagem (2015), mais de 7,7 milhões de pessoas já participaram do evento. Outro aspecto interessante diz respeito ao número de seguidores em redes sociais: a última edição quebrou recordes com mais de 11 milhões de pessoas. Somando todas as atrações foram mais de 1.359 atrações musicais que se apresentaram nos palcos do Rock in Rio, com um total de 1.200 horas de música, com transmissão para mais de 1 bilhão de telespectadores em todo mundo, pela TV e Internet, segundo dados dos organizadores.

No decorrer das edições, mais de U\$530 milhões foram investidos na marca. Na edição de 2013, 46\% da plateia do Rock in Rio era fora do Rio de Janeiro. O impacto econômico dessa edição na cidade, publicado pela RioTur, foi de R\$ 1 bilhão (ROCK IN RIO, 2015).

Ao perceber que poderiam explorar mais o impacto e a repercussão de seu evento, seus organizadores passaram a comercializar produtos relacionados à marca. Estes produtos licenciados também chamados de produtos agregados ou produtos derivados, podem ser encontrados em diversas categorias e muitas vezes continuam sendo comercializados após o término do evento (TURNER, 1997).

Segundo artigo publicado pelo site Administradores, O licenciamento - ou licensing - de propriedade intelectual é a concessão de direitos de uso de determinada propriedade para terceiros com o objetivo de agregar valor ao produto, serviço ou comunicação da empresa licenciada. Podem ser licenciados personagens, imagens de personalidades famosas, obras artísticas e diversos tipos de marcas, como as corporativas, de moda, de clubes esportivos, de programas de TV, filmes de cinema, ONGs, etc. Esse mercado movimentou 13 bilhões de reais no Brasil em 2014, dado mais recente disponível. Isso representa um crescimento de $6 \%$ sobre o ano anterior.

Ainda de acordo com o artigo, as vantagens mais facilmente percebidas nesse processo para o licenciado são o instantâneo reconhecimento e valorização do público, a associação a conceitos e valores ligados à licença, a economia em desenvolvimento de marca e o aumento das vendas.

Para quem é detentor dos direitos da propriedade intelectual, as vantagens incluem a geração de receita adicional, a facilidade e rapidez para explorar 
diferentes segmentos e regiões, a possibilidade de focar sua atividade no desenvolvimento, fortalecimento e controle da propriedade licenciada ou de novas.

Porém, algumas empresas têm uma visão incerta a respeito de alguns aspectos do licenciamento. Não é qualquer marca que obterá sucesso no processo de licenciamento. A marca deve ter não apenas um grande reconhecimento e exposição, mas deve ter público que indica e defende espontaneamente a marca, cria fã-clubes, e até tatuam no corpo a marca. Isso exige não só uma exposição maciça, mas o aprofundamento da essência e da personalidade da marca, de seu contexto, o uso consistente de associações a determinados valores, que são reconhecidos, identificados e valorizados pelo público. É importante também a seleção criteriosa de empresas licenciadas.

Segundo o site AlmanaqueVirtual e o próprio site do evento, o Rock in Rio é reconhecido por ser um influente agente econômico no decorrer de suas edições, movimentando significativamente o mercado do país. Como exemplo disso, podemos perceber a enorme quantidade de produtos licenciados com a marca do evento. Na edição de 2015, que aconteceu em setembro, na Cidade do Rock, Rio de Janeiro, foram 643 itens com a marca Rock In Rio, divididos em 76 categorias. Segundo os organizadores do evento, esses números são um recorde comparado à última edição do festival, quando atingiu uma marca de 600 produtos. Os produtos oficiais do festival vão de peças de vestuário a artigos de higiene, alimentação, beleza, automóveis, dentre outros. (ROCK IN RIO, 2015).

De acordo com o Plano Nacional de Turismo 2013 - 2016 e pelo Ministério do Esporte, considerando o grande sucesso dos megaeventos, estes apresentam maior oferta de produtos agregados, buscando assim proporcionar ao consumidor uma experiência ainda maior e mais real com o evento. Gera também uma maior receita para a organização que detém a marca.

Segundo Kotler e Keller (2006, p.173) "o comportamento do consumidor pode ser influenciado por diversos fatores: os culturais, sociais, pessoais e psicológicos, sendo os fatores culturais que exercem maiores e mais influências". Desta forma, este estudo se propõe a investigar a motivação dos consumidores para comprar produtos oficiais da marca Rock in Rio antes, durante e após o evento. 


\subsection{Objetivo do estudo}

Este trabalho tem como objetivo compreender a motivação das pessoas que se identificam com o Rock in Rio para comprar produtos derivados da marca - antes, durante e após o seu acontecimento.

\subsection{Objetivos intermediários do estudo}

Para se atingir o objetivo final proposto esse estudo prevê alguns objetivos intermediários a serem alcançados no decorrer do mesmo.

(a) Estudar o mercado de produtos oficiais, derivados e licenciados.

(b) Identificar os produtos mais vendidos.

(c) Pesquisar os aspectos que favorecem o relacionamento da empresa com o cliente, influenciando na sua motivação e decisão de compra.

\subsection{Delimitação e foco do estudo}

Este estudo terá como foco principal entender o comportamento do consumidor de produtos oficiais do Rock in Rio, que tenham idade entre 15 e 55 anos, que foram ao evento, pretenderam ir ou que se identifiquem com o Rock in Rio edição 2015, realizado em setembro na cidade do Rio de Janeiro.

Não se pretende medir retornos financeiros e sim ter como objetivo principal questões ligadas ao comportamento do consumidor e motivação de compra de produtos oficiais do evento.

\subsection{Justificativa e relevância do estudo}

O estudo do comportamento do consumidor é de grande importância para que as organizações possam ter o entendimento e a compreensão das necessidades e desejos dos consumidores, possibilitando assim que as empresas possam atendê-los de forma satisfatória.

Desta forma, o presente estudo pretende compreender que um megaevento como o Rock in Rio pode ter uma importância significativa para os consumidores e influenciar no comportamento do mesmo no momento da compra de produtos oficiais do evento. Tal perspectiva de análise apresentada se mostra interessante por tratar de um tema com poucos estudos acadêmicos, principalmente sob aspectos relacionados ao marketing, com um enfoque mais 
específico no comportamento do consumidor e no valor da marca gerado pelo evento e seus produtos oficiais.

As informações que este estudo apresenta pode contribuir para as empresas que atuam no mercado de entretenimento, podendo assim ajudar essas empresas a melhorarem seu desenvolvimento de mercado, tendo como parâmetro informações sobre um evento de grande porte e reconhecimento mundial, além de entenderem de forma mais clara a relação que os consumidores buscam ter com esse mercado.

Então, no âmbito empresarial, o estudo e o entendimento de como se comporta o consumidor representa um aspecto fundamental para o êxito das organizações no mercado onde atuam. Este entendimento contribui para a elaboração de estratégias de marketing relacionadas ao produto. Assim, o conhecimento das características das pessoas, do grupo e do meio em que vivem favorecem a implementação de estratégias corretas em busca da satisfação das necessidades do consumidor.

Para mais, o estudo também se faz relevante para futuras pesquisas e trabalhos acadêmicos, auxiliando em uma possível reflexão sobre o comportamento do consumidor de megaeventos de reconhecimento mundial e seus produtos oficiais. 


\section{Referencial teórico}

Este capítulo tem como objetivo apresentar e discutir a base teórica para o estudo, tendo como fontes principais artigos acadêmicos, livros, além de reportagens de sites de internet, jornais e revistas.

Este capítulo está dividido em três partes e abordam, respectivamente, a marca, a questão de produto cultural, e as perspectivas de comportamento do consumidor, a fim de contextualizar a influência da marca relacionada à motivação de compra dos consumidores.

\subsection{A força da marca como diferencial competitivo}

Uma marca hoje pode ter um valor muito maior do que a própria empresa em si, tal fator é ocasionado devido à grande competitividade no meio empresarial, juntamente com o amadurecimento do consumidor que vem agindo de forma mais seletiva no processo de compra. Tal fator pode ter estimulado empresas de diversos mercados, principalmente o mercado de entretenimento, a buscar a diferenciação através de produtos ou serviços cada vez mais customizados (KOTLER 2000, p.649).

De acordo com KOTLER (2004, p.427), marca é: "Nome, termo, signo ou símbolo, ou uma combinação destes que tem a função de identificar os bens ou serviços de um vendedor ou grupo de vendedores e de diferenciá-los dos concorrentes". Já segundo Chevron (1998), a marca é uma promessa, ou seja, um compromisso com o consumidor e não algo palpável. A marca é um nome que, para além de uma identidade visual, evoca determinadas expectativas, ou seja, refere-se à forma como os consumidores se relacionam com os produtos ou serviços, a personalidade que lhe atribuem a confiança e a lealdade que thes depositam.

Ou seja, marca pode ser definida como qualquer forma que sirva para expressar o que é de fato a empresa ou um produto, e com isso torná-lo diferenciado dos demais. 
Para as empresas, a marca funciona como uma excelente forma de aprimorar seu valor e aumentar o seu reconhecimento. Uma empresa com um bom programa de marketing pode fazer com que suas marcas consigam entrar e se estabelecer em um mercado bastante competitivo onde se têm muitas que já são reconhecidas e respeitadas. Segundo Kotler (2000), saber gerenciar bem uma marca é o fator determinante para que não se tenha problemas futuros de imagem com os seus produtos ou serviços que vão ser entregues ao consumidor.

A construção da marca, portanto, exige mais do que apenas a construção da imagem da marca. Ela requer o gerenciamento de todo contato com a marca que o cliente possa ter. Uma vez que todos os funcionários, distribuidores e revendedores da empresa podem afetar a experiência com a marca, o desafio é gerenciar a qualidade de todos os contatos com a marca. (KOTLER, 2000, p.94).

\subsection{Produto Cultural e Marketing Cultural}

Para entender o Produto Cultural é essencial abordar o que é cultura e mais especificamente marketing cultural, já que estas são os principais aspectos para que se possa discutir esse tema.

Alguns autores abordam ou discutem este conceito, como se pode observar na citação a seguir:

A cultura é o principal determinante do comportamento e dos desejos da(s) pessoa(s). Assim, na medida em que um indivíduo vai ficando mais velho, adquire alguns valores, percepções, preferências e comportamentos influenciados por sua família e de outras instituições."(KOTLER, 2009 p.183).

KOTLER (2000) ainda nos diz que cada cultura possui diversas subculturas inseridas dentro dela, fornecendo assim que os indivíduos que pertencem a ela de alguma forma, possam se socializar e se identificar a partir de grupos raciais, nacionalidade, religião, regiões geográficas.

Com isso, produtos e serviços específicos podem ser criados a partir de uma boa pesquisa de marketing, para grupos específicos que tem suas subculturas acentuadas. As subculturas, segundo Kotler (1998, p.162) são divisões da cultura como, por exemplo, nacionalidade, religiões, grupos raciais e regiões geográficas. Assim, esses produtos geram uma forma de contentar os consumidores, principalmente os brasileiros ou os consumidores da indústria de entretenimento como um todo. 
As manifestações culturais de diferentes formatos e aspectos criam uma forma de divertimento, encantamento e para as organizações ela pode aparecer como um método de relacionamento e comunicação com a sociedade.

Segundo KOTLER E KELLER (2006), marketing em uma definição social pode ser entendido como um processo social pelo qual os grupos e indivíduos tem necessidades e anseiam por meio da criação da oferta e troca de produtos e serviços de valor com outros. Em uma visão gerencial, como a arte de vender produtos.

Para PETER (2000, p.4) o "marketing é o processo de planejar e executar a definição do preço, promoção, distribuição de ideias, bens e serviços com o intuito de criar trocas que atendam metas individuais e organizacionais". Desta forma é possível identificar que o marketing tem uma função importante na venda de produtos ou serviços para a organização. Kotler faz inferência em sua obra, mostrando que o marketing tem a função nos negócios de lidar com os clientes. Tendo ainda como principais objetivos atrair novos clientes, prometendo-Ihes valor agregado superior ao concorrente, mantendo e cultivando clientes atuais, proporcionando-lhes satisfação (KOTLER, 2007).

Constata-se que existem diversos conceitos e definições de marketing que tratam da forma como as pessoas e as organizações se satisfazem. As organizações que tiveram capacidade de reconhecer no Marketing Cultural a possibilidade de melhorar ou de buscar uma imagem de impacto de marca, e levar isso para os seus produtos, estas estão escolhendo uma estratégia diferenciada e inovadora que tem condições de manter e principalmente aprimorar sua imagem de forma positiva para os consumidores e para a sociedade como um todo.

François Colbert(2000), publicou em seu livro que fala a respeito do marketing da cultura e das artes, que a primeira referência ao conceito de marketing de organizações culturais surgiu com a publicação de Kotler ("Marketing Management: Analysis, Planning andControl"), que abordou as estratégias de marketing das organizações culturais.

Marketing cultural é, então, definido como "a arte de atingir aqueles segmentos de mercado que têm potencial interesse pelo produto cultural, ajustando a esse as outras variáveis de marketing preço, distribuição e promoção, de modo a colocar o produto em contato com um número suficiente de consumidores e alcançar os objetivos consistentes com a missão da empresa cultural" (COLBERT, 2000, p.21) 
Colbertdefine produtos culturais como aqueles que são originários de um processo criativo. Os produtos culturais incluem alguns aspectos como experiências ou serviços vividos e sentidos por um público específico. Assim, conseguem suprir o desejo dos consumidores através de informação, divulgação, entretenimento, diversão, lazer, práticas esportivas, relaxamento, enriquecimento cultural, entre outros.

O Marketing Cultural tem como característica uma nova forma das empresas se comunicaram com o seu "público", focando cada vez mais segmentos específicos de consumidores buscando atingi-lo de maneira lúdica e direta.

Cabe à empresa determinar mais precisamente qual a melhor estratégia de Marketing Cultural para por em prática de acordo com o público alvo. Dentre as ações culturais que podem ser utilizadas encontramos, por exemplo, "eventos, shows, amostras, bienais, criação de produtos culturais. (PORTALEDUCAÇÃO).

Dessa forma o Marketing Cultural é uma estratégia para empresas que visam reduzir custos e adquirir vantagem competitiva e, consequentemente, investir em conhecimento, artes, entretenimento, crenças, moral, lei, costumes e todas as demais capacidades e hábitos adquiridos pelo homem enquanto membro de uma sociedade (NETO, 2002, p. 17).

O produto central pode ser considerado o que atende as necessidades específicas do consumidor, já o produto secundário tem uma relação muito próxima com o central, pois oferecem benefícios adicionais ao produto principal, porém o objetivo é melhorar a experiência de compra e diferenciá-lo dos demais concorrentes. Desta forma, percebe-se que as organizações estão buscando que o consumidor consiga ter a consciência do que de fato está sendo oferecido como produto central ou principal e o que poder ser considerado como uma oferta secundária. (LOVELOCK e WRIGHT, 2001). Através desta análise podese concluir então, que no ponto de vista dos eventos musicais, os shows são a oferta principal, e os produtos licenciados ou oficiais são as ofertas secundárias.

Com base na classificação de KOTLER (2000), os produtos de consumo podem ser apresentados de quatro maneiras distintas: produtos de compra comparada, produtos de conveniência, produtos de especialidade e produtos não procurados.

Os produtos de compra comparada são os produtos que os consumidores consomem com menor frequência, e cujas características de preço, qualidade, estilo, são comparadas com outros produtos de forma cuidadosa e cautelosa. Os 
consumidores gastam tempo e esforço relativo na busca por informações e fazendo comparações ao comprar esses produtos.

Já os produtos de conveniência são os que os consumidores compram com maior frequência e rapidez, onde não se tem um processo de comparação e esforço tão expressivo quanto os produtos de compra comparada.

Ao realizar uma compra de produtos de especialidade, os consumidores se esforçam mais para efetuar a compra, podendo chamar de um esforço especial, pois são produtos onde eles têm identificação com a marca e características mais singulares.

Finalmente, os produtos não procurados, são produtos de consumo que o comprador não conhece, o que estão na memória dela, porém não tem vontade nenhuma de comprar. Muitas vezes os consumidores não sabem da existência do produto mesmo ele sendo inovador, pois não tem a consciência de sua existência no mercado.

De acordo com essas formas apresentadas por KOTLER (2000), pode-se perceber que os produtos culturais podem se enquadrar em todas as classificações, podendo alterar de acordo com a percepção do consumidor sobre o produto.

\subsection{Produtos Oficiais ou Licenciados}

O mercado de produtos licenciados, introduzido no Brasil em 1940, se apresenta como uma ferramenta de marketing que as empresas utilizam aliando suas marcas já consagradas ou em processo de consolidação a outras marcas/personagens já conhecidas no mercado, gerando faturamento adicional, ou até mesmo, sobrevivendo no mercado somente com os licenciamentos. Segundo a especialista em Estratégias de Marketing Luciana Maria Bohn. Dentre os produtos licenciados, nas mais diversas categorias, citam-se como exemplos brinquedos, vestuário, materiais escolares, produtos de higiene, entre outros.

De acordo com a Revista Licensing (2012), o fato é que poucas empresas possuem experiência com o uso de marcas de terceiros em seus produtos. No Brasil, especificamente, o mercado cresce muito, mas ainda é tímido. Menos de $1 \%$ das empresas que fabricam e comercializam artigos de consumo licenciam. Diante desse fato, os licenciantes de marcas (entende-se marcas e personagens), apontam como principais barreiras ou dificuldades a falta de informação e material disponível sobre o negócio. O preconceito sobre a real necessidade de licenciar marcas de terceiros acaba prevalecendo e muitas 
empresas perdem grandes oportunidades de explorar o potencial deste mercado.

Os grandes eventos passaram a ter uma grande variedade de produtos e artigos culturais que são entregues aos consumidores e com isso, passaram a deixar de ser um produto único. As formas como as pessoas desejam ir à um festival de música estão completamente ligadas a outros fatores que influenciam diretamente no desejo especificamente, como status, novidade, fatores temporais, recordação e desejo de posse. (SEBRAE).

Com isso, os profissionais de marketing começam a perceber que os eventos de música são uma porta para o sucesso e para a consolidação de uma grande marca na indústria de entretenimento em esferas nacionais e internacionais, pois se consegue ter uma visão que vai além de ser só um show ou só um evento, se transformando em outros produtos e serviços (MOVIMENTO, 2009).

Do ponto de vista de megaeventos mundiais, os produtos licenciados começam a ter sua venda com certa antecedência do evento, para que os consumidores criem uma identidade com a marca e um reconhecimento ao assimilar que alguns de seus produtos do dia a dia estão com o nome e são considerados produtos oficiais, levando o nome da marca em suas embalagens. Também são comercializados durante o festival, onde muitas vezes conseguem ter uma venda muito expressiva, pois os consumidores buscam ter uma recordação do momento que está vivenciando, ou até mesmo como produtos que possam suprir uma necessidade momentânea, como é o caso do Tomorrowland (um dos maiores eventos de música do planeta), onde, segundo comentários em grupos nas redes sociais relacionados ao evento, pessoas acabaram comprando alguns produtos para suprir a falta de algo que não esqueceu de levar como casaco, chinelo, camiseta, boné, dentre outros.

\subsection{Motivação}

De acordo com KOTLER (2000), um motivo ou impulso é uma necessidade que está pressionando suficientemente uma pessoa a agir, é uma força interna não observável que estimula e compele a uma resposta comportamental, fornecendo uma orientação específica para essa resposta. 
Segundo Schiffman e Kanuk (2000), a motivação é a força motriz interna dos indivíduos que os impele à ação, a qual é produzida por um estado de tensão, que existe uma vez que há uma necessidade não satisfeita.

\subsubsection{Processo de Motivação}

Geralmente, através dos esforços de marketing, uma necessidade que não tinha sido percebida pelo consumidor de uma forma consciente, pode vir a se tornar algo pertinente para o seu desejo. O poder do marketing pode fazer com que o consumidor perceba que de alguma forma o produto ou serviço que está sendo oferecido pode ser suficiente para suprir suas necessidades e resolver seus problemas. Com base nisso, saber qual é de fato o motivo que move o consumidor a querer comprar ou ter o desejo de comprar é algo de suma importância para que se possa estruturar as estratégias de comunicação que vão tornar mais consciente essa necessidade (BRASILESCOLA).

Segundo SOLOMON (2002), a motivação pode ser definida então, como os processos que fazem com que as pessoas se comportem do jeito que se comportam, ocorrendo principalmente através da ativação de uma necessidade onde o consumidor vai querer satisfazê-la. A partir do momento que essa necessidade é ativada, o consumidor vai vivenciar um estado que vai impulsioná-lo a tentar diminuir ou eliminar essa necessidade, alcançando seu objetivo final, o estado de satisfação pós compra.

As motivações associam-se muitas vezes às necessidades e desejos, no entanto, existem diferenças substanciais. Pode definir-se a motivação como a busca de satisfação da necessidade, que diminui a tensão ocasionada por ela.

Para KOTLER (2000), os desejos são carências por satisfações específicas para atender às necessidades e são moldados pela cultura e pelas características pessoais.

Os fatores pessoais e culturais se combinam para criar o desejo. $O$ desejo é a necessidade de um indivíduo que não é satisfeita, ou seja, é moldado pelas características, modo de pensar, agir, pela cultura de cada um. O objetivo do marketing é identificar as necessidades e criar desejos nos indivíduos, tornando os produtos atraentes e disponíveis para o consumidor (ESTGV). 


\subsubsection{Teorias da Motivação}

Cada indivíduo tem um conjunto de necessidades que precisam ser atendidas, quando ele se depara com uma necessidade não satisfeita, gera um estado de desequilíbrio. $O$ indivíduo é internamente pressionado para resolver o problema, buscando soluções que Ihe permita atender aquela necessidade, esse impulso para a ação, em busca do equilíbrio, é caracterizado como motivação.

Em relação às necessidades, Kotler (2000) relaciona as três teorias mais conhecidas para motivação humana: a de Sigmund Freud, a de Abraham Maslow e a de Frederick Herzberg.

\subsubsection{Teoria de motivação de Freud}

Freud concluiu que as forças psicológicas reais que moldam o comportamento das pessoas são inconscientes e que ninguém chega a entender por completo as próprias motivações (KOTLER; KELLER, 2006 p.183).

A teoria de Freud estabelece que as motivações são responsáveis pela aceitação e rejeição de determinados produtos ou serviços. Este fato pode ser mais fácil de ser compreendido analisando-se três instâncias psíquicas responsáveis pelo comportamento descritas por Freud: o id (fonte da energia psíquica dos impulsos primitivos), o ego (regulador dos impulsos selvagens do id ligado ao princípio da realidade) e o superego (a quem cabe a representação interna das proibições sociais) (FREUD, 1980).

Quando uma pessoa avalia marcas, ela reage não apenas às possibilidades declaradas dessas marcas, mas também a outros sinais menos conscientes.

\subsubsection{Teoria da motivação de Maslow}

A segunda teoria é a de Abraham Maslow, que descreve as necessidades fundamentais, que para ele, motivam o homem. Tais necessidades são organizadas numa hierarquia, partindo das mais urgentes às menos urgentes. Em ordem de importância, elas são necessidades fisiológicas, necessidade de segurança, necessidade sociais, necessidade de estima e necessidade de autorealização como apresenta a figura abaixo: 
Figura 1 - Pirâmide de Maslow

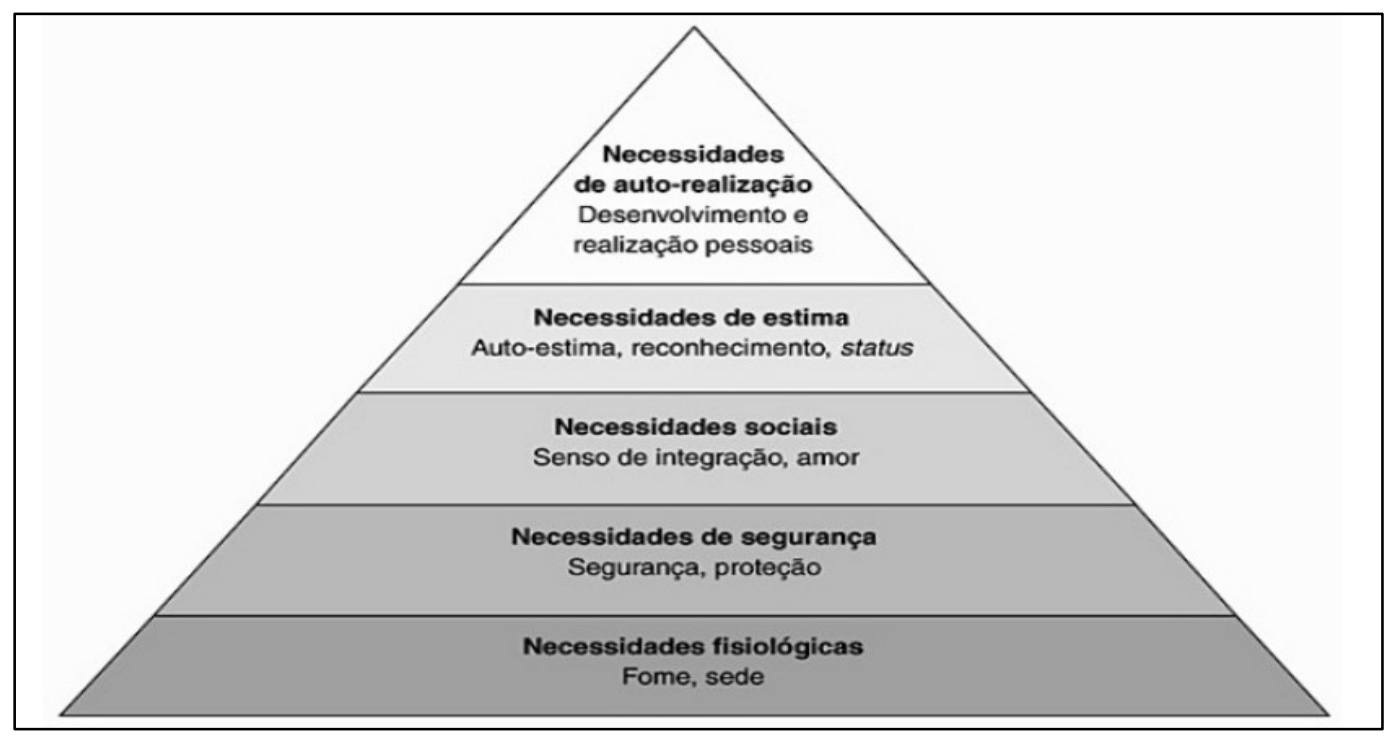

Fonte: KOTLER E ARMSTRONG (2007, p. 123).

As pessoas tentam satisfazer as mais importantes em primeiro lugar. Quando conseguem satisfazer uma necessidade importante, tentam satisfazer a necessidade seguinte definida como mais importante. Karsaklian (2000) diz que a hierarquização das necessidades na pirâmide de Maslow obedece a uma escalonagem que é repassada na medida em que a necessidade anterior é satisfeita.

Na base da pirâmide estão as necessidades fisiológicas do individuo, que podem ser caracterizadas como a fome, sede, sexo, sono, entre outros. São as mais urgentes e guiam fortemente o comportamento caso não estejam satisfeitas. De acordo com que as necessidades fisiológicas estão satisfeitas, as de segurança começam a surgir. As necessidades de segurança que levam cada indivíduo a procurar proteção de qualquer perigo.

Após a satisfação dessas duas necessidades, apresentam-se as necessidades de segurança que são aquelas que estão vinculadas com as necessidades de sentir-se seguros: sem perigo, em ordem, com segurança, de conservar o emprego etc. No trabalho: emprego estável, plano de saúde, seguro de vida etc.

As necessidades de estima se referem aos desejos das pessoas por uma auto-estima elevada. A satisfação desta necessidade gera sentimentos de autoconfiança, de valor, de reconhecimento, status e sentimento de utilidade. Porém, se essa necessidade é frustrada, pode levar o indivíduo a encarar sentimentos de inferioridade, fraqueza e desamparo. 
No topo da pirâmide, Maslow define as necessidades de auto-realização que se referem a realização, aproveitar todo o potencial próprio, ser aquilo que se pode ser, fazer o que a pessoa gosta e é capaz de conseguir. Relaciona-se com as necessidades de estima: a autonomia, a independência e o auto controle.

\subsubsection{Teoria da motivação de Herzberg}

A teoria de Herzberg é definida como a teoria que apresenta os fatores insatisfatórios, aqueles que causam insatisfação e os satisfatórios, aqueles que causam satisfação (MOTTA E VASCONCELOS, 2006, p.74).

O produto não pode ter apenas a ausência dos "insatisfatores", mas deve contar também com a presença dos "satisfatores" a fim de motivar a compra. $\mathrm{Na}$ escolha de um determinado produto o consumidor é afetado pelas circunstâncias econômicas: renda disponível (nível, estabilidade e periodicidade) economias e bens (incluindo o percentual líquido), débitos, capacidade de endividamento, atitude em relação a gastar versus economizar. (KOTLER; KELLER, 2006).

\subsection{Comportamento do Consumidor}

O comportamento do consumidor, para SOLOMON (2011, p.33) "é o estudo dos processos envolvidos quando indivíduos ou grupos selecionam, compram, usam ou descartam produtos, serviços, ideias ou experiências para satisfazer necessidades e desejos".

Com o aumento da competitividade das organizações e da concorrência do mercado, surge a busca por alternativas que possam satisfazer as necessidades do consumidor. Desta forma, o comportamento de compra do consumidor vem passando por um processo de transformação, onde os consumidores vem se tornando cada vez mais exigentes, buscando a satisfação de suas necessidades e este estudo pretende mostrar a importância de identificar seus hábitos e preferências (ADMINISTRADORES).

\subsubsection{Tipos de consumidores}

Para Kotler e Keller (2006 apud REIS, 2007), é possível identificar quais grupos de consumidores estariam dispostos a utilizar determinado produto, bem como saber em qual época do ciclo de vida do produto eles estariam mais 
propensos a efetuar a compra. A adoção é a decisão de alguém de se tornar usuário regular de um produto e está dividida em cinco fases:

- Conscientização: quando o consumidor se conscientiza da existência de um determinado produto;

- Interesse: quando o consumidor potencial passa a ter interesse pelo produto e busca informações sobre ele;

- Avaliação: quando o consumidor passa a avaliar o risco e o custo da experimentação;

- Experimentação: fase em que o consumidor experimenta o produto e faz uma avaliação se vai ou não comprá-lo;

- Adoção: quando o consumidor aprova o produto e o adota.

Diante das fases de adoção descritas acima, Kotler (apud REIS, 2007) consegue identificar quais são os tipos de consumidores, como pode ser visto a seguir:

Os inovadores que são os consumidores extravagantes e que gostam de assumir riscos, porém não são formadores de opinião e também não servem como referência de consumo para a grande massa. Já os adotantes imediatos são classificados como consumidores altamente respeitados por seus grupos. Esse grupo é considerado de grande importância para a organização, pois contribui para o estágio de crescimento e para o incremento do volume de vendas necessário para investimento nos novos produtos. Os de maioria imediata são consumidores cuidadosos e não gostam de correr riscos. São também responsáveis pelo crescimento do lucro na fase de maturidade. Já os de maioria tardia, são consumidores expressivamente cautelosos, não gostam de correr riscos e ainda possuem resistência à adoção de um produto novo. São conservadores e só passam a adotar um produto quando já é utilizado pela maioria consumidora. Por fim, os retardatários são consumidores tradicionais. Para eles, a compra de um produto novo traz uma sensação de extremo desconforto psicológico. Não gostam de novidades, inclusive fogem delas, e consideram imatura a compra de um artigo inovador no mercado.

\subsubsection{Influências no processo de compra}

O comportamento do consumidor pode ser influenciado por diversos fatores no momento da compra. Esses fatores podem ser culturais, sociais, 
pessoais e psicológicos (Figura 2). O estudo destes fatores é de grande importância para que se entenda porquê o consumidor se comporta de determinada maneira, ou seja, quais são os fatores que influenciam o comportamento do consumidor.

Figura 2 - Fatores de influência no processo de decisão de compra

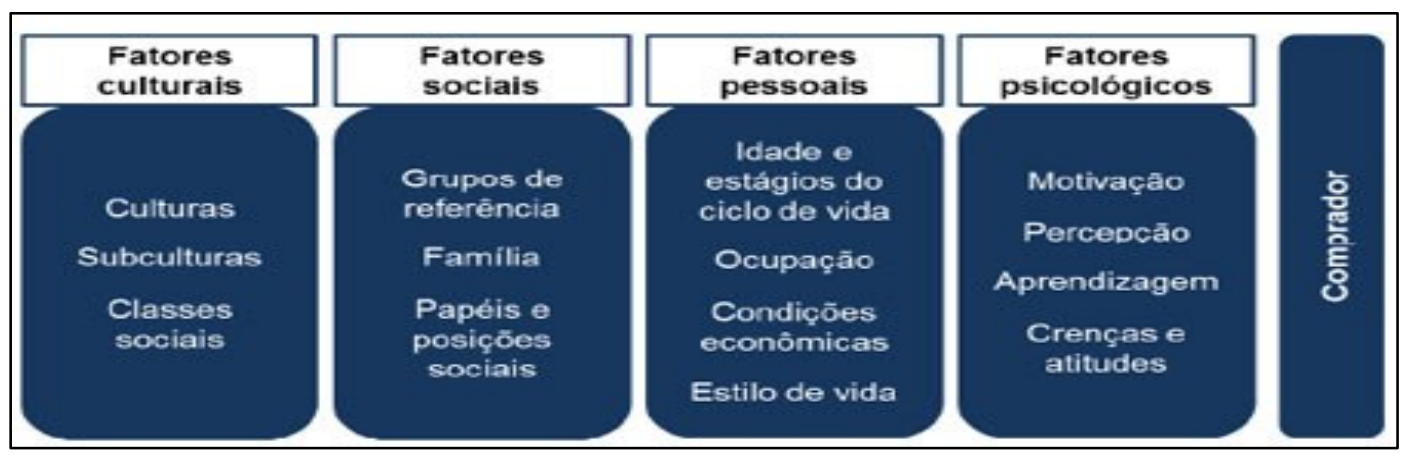

Fonte: $\operatorname{KOTLER}(1998, p .163)$

Segundo Kotler e Keller (2006), os fatores culturais são os que exercem a mais ampla e profunda influência sobre os consumidores. Segundo Sobral e Pecci (2008), dentre os diversos fatores ambientais, a cultura é um dos principais determinantes do comportamento do consumidor, é por meio da mesma que as pessoas adquirem valores, crenças, costumes e preferências que a levarão a adotar determinados comportamentos de consumo.

A cultura afeta os produtos específicos que as pessoas compram, assim como a estrutura de consumo, a tomada de decisão individual e comunicação numa sociedade (ENGEL; BLACKWEEL; MINIARD, 2000).

Os fatores sociais podem ser classificados como os grupos de referência, tais como família, papéis e posições sociais que acabam por influenciar o comportamento de compra (KOTLER; KELLER, 2006). De acordo com Shiffman e Manuk (200), determinados fatores como: os grupos, família, papéis e status exercem alto grau de influência sobre as pessoas. Para o marketing, os grupos de referência servem como grandes influenciadores para os comportamentos ou atitudes específicas dos indivíduos no momento de suas compras ou decisões de compra, permitindo que as pessoas ou grupos assumam um papel de comparativos.

Uma pessoa pertence a vários grupos como família, clubes e organizações e sua posição em cada um deles pode ser definida em termos tanto de papel quanto de status. Nos diferentes grupos sociais nos quais as pessoas participam 
ao longo de suas vidas, elas acabam assumindo diferentes papéis e posições sociais. Neste sentido, é fato que as pessoas, como diz Kotler (1998), escolham produtos que comuniquem seu papel e status na sociedade. As pessoas segundo Kotler e Amrstrong (2007), escolhem produtos apropriados para seus papéis e status.

Os fatores pessoais são ditos como as características particulares de cada individuo, momentos e vivências que a pessoa está passando, que interferem diretamente nos hábitos e nas decisões de consumo. Nesse sentido, apresentam-se características pessoais, como idade e estágio no ciclo de vida, ocupação, situação financeira, estilo de vida, personalidade e auto-imagem (KOTLER, 1998).

A escolha de compra do consumidor passa por alguns estados como: existência de uma necessidade, consciência desta necessidade, conhecimento do objeto que a pode satisfazer, desejo de satisfazê-la e decisão por determinado produto. Uma pessoa tem muitas necessidades em determinado momento, algumas dessas necessidades são biológicas, outras são psicológicas, causada pela necessidade de reconhecimento ou impulso, é uma necessidade suficientemente forte fazer com que as pessoas busquem satisfazêlas. Assim, conforme KOTLER (1998), existem quatro fatores psicológicos que influenciam as escolhas dos consumidores: motivação, percepção, aprendizagem, crenças e atitudes.

Por meio desses fatores que influenciam o comportamento do consumidor, empresas buscam construir uma estratégia de comunicação para seus produtos que corresponda aos anseios do seu público alvo. Segundo Kotler e Keller 2006, a comunicação de marketing representa a "voz" da marca e é o meio pelo qual ela estabelece uma relação com os consumidores.

Ainda segundo Kotler, os estímulos internos são as necessidades normais de uma pessoa. Já os estímulos externos, são percepções que as pessoas têm acerca de situações que podem influenciá-las, Sendo assim, Kotler descreve um modelo chamado de estímulo e resposta (Figura 2) para buscar o entendimento do comportamento do comprador. "As características do comprador e seus processos de decisão levam a certas decisões de compra, influenciados pelos fatores culturais, sociais, pessoais e psicológicos, onde os fatores culturais exercem a maior e mais profunda influência" (KOTLER, 2000, p.183). 
Figura 3 - Modelo de estímulos e resposta.

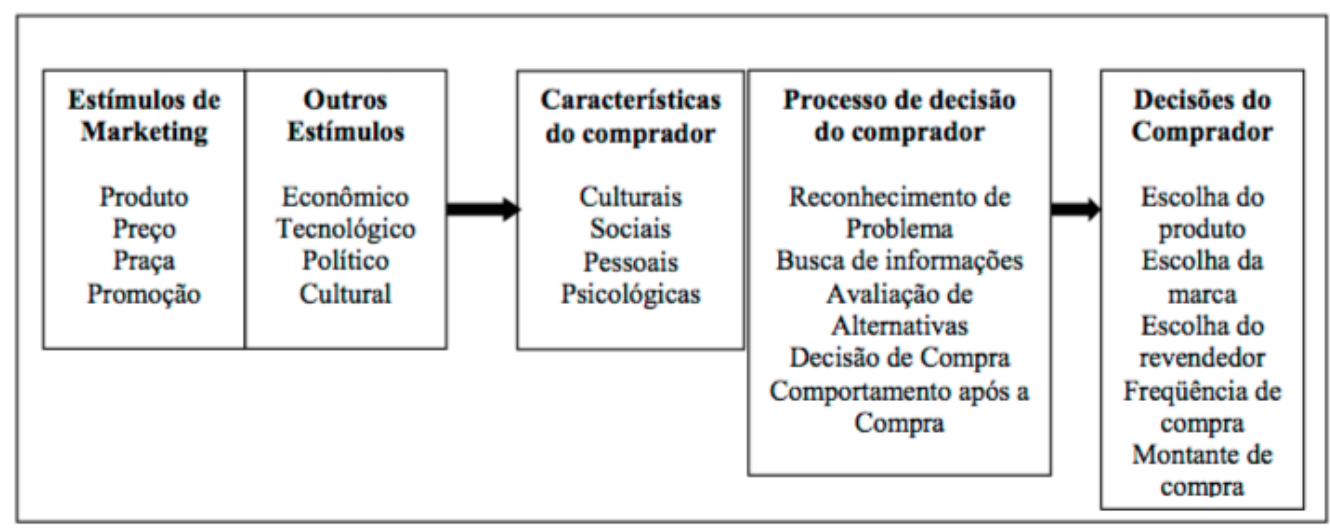

Fonte: KOTLER, 2000, p.183.

O comportamento de compra do consumidor é influenciado por vários fatores. Através do modelo de estímulo e resposta de Kotler (2000) pretende-se apresentar como os estímulos de marketing tem relação direta com as decisões de compra do consumidor.

Como mostra a Figura 3, os estímulos de marketing são percebidos através do mix ou composto de marketing (preço, produto, praça e promoção), estímulos econômicos, tecnológicos, político e cultural, as características dos consumidores (culturais, sociais, pessoais e psicológicas), o processo de decisão do consumidor (reconhecimento do problema, busca de informações, avaliação de alternativas, decisão de compra e comportamento pós-compra), e por último as decisões do comprador (escolha do produto, escolha da marca, escolha do revendedor, freqüência de compra e montante de compra).

\subsubsection{Necessidade}

Segundo KOTLER (2000 p.33), as necessidades descrevem exigências humanas básicas. As pessoas precisam de recreação, educação e entretenimento. Essas necessidades se tornam desejos quando são dirigidas a objetos específicos capazes de satisfazê-las. Um norte-americano necessita de comida, mas deseja um hambúrguer, batatas fritas e um refrigerante. Um habitante das ilhas Maurício necessita de comida, mas deseja uma manga, arroz, lentilhas e feijão. Ainda de acordo com KOTLER (2000 p.33):"Desejos são moldados pela sociedade em que se vive".

As necessidades humanas são o ponto de partida do marketing, segundo KOTLER (2000). Elas resultam das situações de privação e são elementos 
básicos da condição humana. Pode-se exemplificar as necessidades básicas como: alimentação, vestuário, segurança, afeto, amor, auto expressão.

Estudar a necessidade é compreender o ponto de partida para o processo de motivação, ela pode ser percebida no momento em que se nota a diferença entre o estado real e o estado desejado do consumidor. Sendo assim, é uma condição de insatisfação vivida por um indivíduo fazendo com que ele procure uma resolução para solucionar tal problema.

As necessidades não podem ser criadas por estímulos externos, porque elas são fatores individuais pertencentes a cada indivíduo. Um bom profissional de marketing pode, através de campanhas publicitárias, buscar uma forma de estimular a preferência do consumidor, ou de estimular o desejo de compra do consumidor para o produto ou marca que esteja trabalhando.

Segundo MASLOW (1970) apud GUIMARÃES (1999, página), e como mostra a Figura 4, a Teoria das Necessidades considera que as necessidades humanas estão dispostas ao longo de uma escala hierárquica em cinco níveis (necessidade fisiológicas, segurança, sociais, estima e auto-realização) sendo que as necessidades mais básicas devem ser atendidas primeiro, para que as subsequentes passem a ter importância. Na medida em que uma necessidade é preenchida, ela perde sua capacidade motivacional e as subsequentes passam a ser o foco. Fazendo uma relação entre esta hierarquia, a abordagem das necessidades e desejos de KOTLER (2000) e as funções de um produto, GUIMARÃES (1999) propõe que estas assumem menor ou maior peso conforme o tipo de produto ou a necessidade do usuário: a função prática é mais premente quando ainda há necessidades básicas a preencher. As funções estética e simbólica preponderam quando a função primária do produto já foi atendida, e o usuário precisa satisfazer seus desejos de pertinência a um dado grupo ou de referência a um status. 
Figura 4 - Relação entre necessidades e desejos, a hierarquia de necessidades, e a três funções básicas de um produto

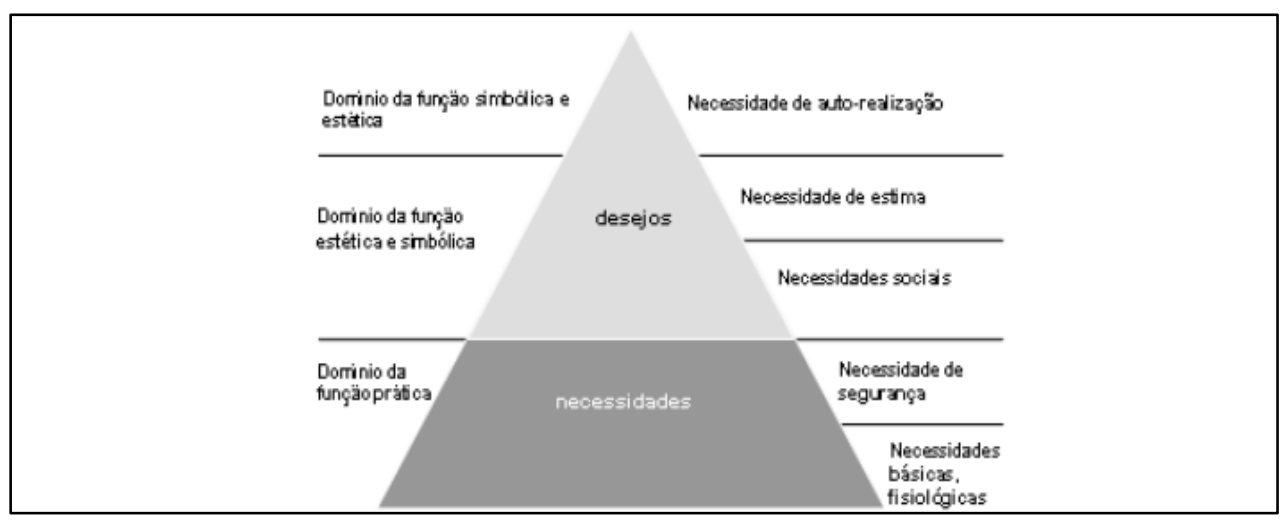

Fonte. Relação entre necessidades e desejos (KOTLER, 2000, p.525), a hierarquia de necessidades de Maslow (1970), e as três funções básicas de um produto (LOBACH, 2009). 


\section{Métodos e procedimentos de coleta e de análise de dados do estudo}

\subsection{Etapas de coleta de dados}

O estudo contou com levantamentos em fontes secundárias no primeiro capítulo, tais como notícias retiradas da internet e dados de sites que continham informações específicas sobre o tema, abrangendo principalmente dados sobre o mercado, da empresa e de pessoas influentes sobre o assunto.

Depois para criação de uma base teórica, foram utilizados livros, dissertações e teses acadêmicas para fundamentar todo o estudo que vinha a ser realizado.

Este estudo foi realizado em três etapas, que permitiram atingir os objetivos primários e secundários do estudo:

A primeira etapa foi uma pesquisa exploratória de caráter qualitativo, através de entrevistas individuais com roteiro semiestruturado, realizado com possíveis consumidores do produto Rock in Rio, não tendo como pré-requisito ter ido ao evento. As entrevistas buscaram coletar informações que serviram de base para a segunda etapa da pesquisa.

A utilização da pesquisa exploratória, de acordo com GIL (1996, p.54), é cada vez mais frequente nas ciências humanas, sobretudo na Psicologia, na Psicologia Social (por exemplo: medição de atitudes, estudo do comportamento de pequenos grupos, análise dos efeitos da propaganda, etc.).

A pesquisa exploratória também é utilizada para assuntos com pouco estudo anterior a respeito, e permite maior proximidade do pesquisador com o tema escolhido, visando a descoberta e o achado de informações relevantes ao estudo, tornando o problema da pesquisa mais explícito.

$\mathrm{Na}$ segunda etapa da pesquisa de campo, foi elaborado um questionário com o objetivo de determinar os fatores de influência no processo de motivação de compra dos produtos oficiais do Rock in Rio, tendo-se consumidores finais como sujeitos da pesquisa, bem como seus influenciadores.

O questionário foi aplicado online e para sua realização, foi enviado um "comunicado" com um texto explicativo sobre a pesquisa e um link da plataforma 
Qualtrics com um questionário. O Qualtrics é uma plataforma de pesquisa fácil e dinâmica para capturar, analisar e criar relatórios de pesquisa. O questionário ficou ativo por uma semana entre os dias 10/05 e 19/05/2016 e contou com 128 respondentes.

\subsection{Fontes de informação selecionadas para coleta de dados no estudo e amostra}

A referida pesquisa foi constituída de fontes primárias e secundárias.

As fontes secundárias consistem de bibliografias específicas, estudos acadêmicos relativos ao tema, informações do Ministério da Cultura, ANPAD, SEBRAE e PWC, como fonte de dados do mercado, informações pertinentes ao tema e sobre o conteúdo abordado.

As fontes primárias foram consultadas através de uma pesquisa de campo em duas etapas: a primeira, uma pesquisa qualitativa em profundidade como apresentado no Anexo 1 - Roteiro semiestruturado para as entrevistas, com um grupo de 8respondentes. As informações obtidas nesta etapa ajudaram a estruturar o questionário quantitativo. A seleção de sujeitos considerou tantas pessoas que foram quanto pessoas que não foram ao Rock in Rio. Também poderiam ou não ter comprado algum produto relacionado ao evento. O grupo entrevistado foi composto por jovens entre 19 e 25 anos, pertencentes à classe A e B, como mostra o Quadro 1 abaixo.

\section{Quadro 1 - Perfil dos Entrevistados}

\begin{tabular}{|c|c|c|c|c|}
\hline N & IDADE & PROFISSÃO & $\begin{array}{c}\text { FORAM AO } \\
\text { EVENTO }\end{array}$ & $\begin{array}{c}\text { CLASSE } \\
\text { SOCIAL }\end{array}$ \\
\hline 1 & 25 & ESTUDANTE & SIM & A \\
\hline 2 & 21 & ESTUDANTE & SIM & A \\
\hline 3 & 24 & ESTUDANTE & SIM & B \\
\hline 4 & 25 & ESTUDANTE & SIM & B \\
\hline 5 & 24 & ANALISTA JR. & SIM & A \\
\hline 6 & 19 & ESTUDANTE & NÃO & A \\
\hline 7 & 22 & ESTUDANTE & NÃO & A \\
\hline 8 & 25 & ESTUDANTE & NÃO & A \\
\hline
\end{tabular}

Fonte: o autor (2016)

Durante esta etapa pode ter ocorrido um viés, levando em consideração que os entrevistados foram pessoas próximas ao ciclo de convivência do 
pesquisador e podem ter dado respostas que auxiliassem a pesquisa. A seleção de sujeitos foi, portanto, por acessibilidade.

A segunda etapa da pesquisa de campo consistiu de uma pesquisa quantitativa com os consumidores sobre os produtos do Rock in Rio. Para isso, foi elaborado um questionário, com questões relacionadas às práticas de compra e influências no momento de compra, como apresentado no Anexo 3 Questionário sobre compra do produto do Rock in Rio. A amostra foi selecionada por acessibilidade, através do envio do link de pesquisa para um grupo próximo ao pesquisador, a referida amostra contou com 128 respondentes. O grupo consiste de pessoas de diferentes idades, em sua maioria jovens de 18 a 25 anos de idade, moradores do Rio de Janeiro que frequentaram o evento, gostariam de ter ido, ou que se identificam com o evento. As tabelas abaixo mostram o perfil dos entrevistados do estudo.

\section{Tabela 1 - Gênero}

\begin{tabular}{|l|l|l|l|}
\hline \multicolumn{1}{|c|}{ Resposta } & Barra & \% \\
\hline 1 & Masculino & & $50.00 \%$ \\
\hline 2 & Feminino & & $50.00 \%$ \\
\hline & Total & & $100.00 \%$ \\
\hline
\end{tabular}

Fonte: informações retiradas do resultado dos questionários feito com os consumidores.

Tabela 2 - Faixa Etária

\begin{tabular}{|c|c|c|c|}
\hline$\#$ & Resposta & Barra & $\%$ \\
\hline 1 & até 18 anos & प & $2.56 \%$ \\
\hline 2 & de 18 a 25 anos & $\square$ & $67.95 \%$ \\
\hline 3 & de 25 a 35 anos & $\square$ & $20.51 \%$ \\
\hline 4 & de 35 a 45 anos & $\square$ & $3.85 \%$ \\
\hline \multirow[t]{2}{*}{5} & acima de 45 anos & $\square$ & $5.13 \%$ \\
\hline & Total & & $100.00 \%$ \\
\hline
\end{tabular}

Fonte: informações retiradas do resultado dos questionários feito com os consumidores. 
Tabela 3 - Escolaridade

\begin{tabular}{|l|l|c|c|}
\hline$\#$ & \multicolumn{1}{|c|}{ Resposta } & Barra & $\%$ \\
\hline 1 & Ensino Fundamental - Incompleto & $0.00 \%$ \\
\hline 2 & Ensino Fundamental - Completo & $0.00 \%$ \\
\hline 3 & Ensino Médio - Incompleto & & $0.00 \%$ \\
\hline 4 & Ensino Médio - Completo & $5.13 \%$ \\
\hline 5 & Ensino Superior - Incompleto & & $56.41 \%$ \\
\hline 6 & Ensino Superior - Completo & & $26.92 \%$ \\
\hline 7 & Pós-graduação - Incompleto & & $5.13 \%$ \\
\hline 8 & Pós-graduação - Completo & & $6.41 \%$ \\
\hline & Total & & $100.00 \%$ \\
\hline
\end{tabular}

Fonte: informações retiradas do resultado dos questionários feito com os consumidores.

Tabela 4 - Estado Civil

\begin{tabular}{|l|l|l|l|}
\hline$\#$ & \multicolumn{1}{|c|}{ Resposta } & Barra & $\%$ \\
\hline 1 & Solteiro & & $62.82 \%$ \\
\hline 2 & Em um relacionamento & & $28.21 \%$ \\
\hline 3 & Casado & $\square$ & $6.41 \%$ \\
\hline 4 & Divorciado & & $2.56 \%$ \\
\hline 5 & Viúvo(a) & & $0.00 \%$ \\
\hline & Total & & $100.00 \%$ \\
\hline
\end{tabular}

Fonte: informações retiradas do resultado dos questionários feito com os consumidores.

Tabela 5 - Renda Familiar Mensal

\begin{tabular}{|l|l|l|l|}
\hline$\#$ & \multicolumn{1}{|c|}{ Resposta } & Barra & $\%$ \\
\hline 1 & Até $\mathrm{R} \$ 1.576,00$ & & $7.69 \%$ \\
\hline 2 & De $\mathrm{R} \$ 1.576,01$ a $\mathrm{R} \$ 3.152,00$ & $16.67 \%$ \\
\hline 3 & De $\mathrm{R} \$ 3.152,01$ a $\mathrm{R} \$ 7.880,00$ & & $38.46 \%$ \\
\hline 4 & De $\mathrm{R} \$ 7.880,01$ a $\mathrm{R} \$ 15.760,00$ & $17.95 \%$ \\
\hline 5 & R\$15.760,01 ou mais & & $19.23 \%$ \\
\hline & Total & & $100.00 \%$ \\
\hline
\end{tabular}

Fonte: informações retiradas do resultado dos questionários feito com os consumidores. 


\subsection{Procedimentos e instrumentos de coleta de dados utilizados no estudo}

As informações de fontes secundárias foram colhidas utilizando-se pesquisa em base de dados, leitura de livros acadêmicos e busca da internet.

A primeira etapa da pesquisa de campo, de caráter qualitativo, foi realizada através de entrevistas pessoais em profundidade, a informações coletadas foram tratadas de forma qualitativa, a partir da análise de conteúdo. Essa etapa qualitativa possuía um roteiro semi-estruturado que abordava dados a respeito da ida ao evento, comportamento, influência e motivo de compra ou não compra do produto. Essas entrevistas tiveram duração de no máximo 7 minutos.

A pesquisa, quando qualitativa, opera uma compreensão profunda de certos fenômenos sociais, apoiados no pressuposto do aspecto subjetivo da ação social, visto que foca fenômenos complexos e/ou únicos. "O termo qualitativo implica uma partilha densa com pessoas, fatos e locais que constituem objetos de pesquisa, para extrair desse convívio os significados visíveis e latentes que somente são perceptíveis a uma atenção sensível" (CHIZZOTTI, 2006, p. 1), pois, os estudos qualitativos descrevem a complexidade de determinado problema e a interação de certas variáveis.

VERGARA (2005) nos diz que análise de conteúdo são abordagens qualitativas, partir de categorização, que focam nas peculiaridades, dando mais importância à relevância do conteúdo descoberto e não a sua frequência

A segunda etapa da pesquisa de campo, de caráter quantitativo foi realizada enviando um "comunicado" com um texto explicativo sobre a pesquisa e um link do Qualtrics com um questionário. O Qualtrics é uma plataforma de pesquisa fácil e dinâmica para capturar, analisar e criar relatórios de pesquisa. Pode-se definir questionário como a técnica de investigação composta por um conjunto de questões que são submetidas a pessoas com o propósito de obter informações sobre conhecimentos, crenças, sentimentos, valores, interesses, expectativas, aspirações, temores, comportamento presente ou passado, segundo GIL (2010).

Construir um questionário consiste basicamente em traduzir objetivos da pesquisa em questões específicas. Assim, foi escolhido o questionário para identificar práticas de compra e sua influência no momento da compra. Tem 
como propósito então, obter informações necessárias sobre o que motiva o consumidor a comprar os produtos oficiais do Rock in Rio.

\subsection{Formas de tratamento e análise dos dados coletados para o estudo}

$\mathrm{Na}$ etapa qualitativa, as entrevistas em profundidade com os consumidores foram gravadas, transcritas de acordo com o Anexo 2 - Transcrição da Entrevistas em Profundidade, e logo em seguida foram analisadas as respostas de acordo com o roteiro que foi respondido (roteiro positivo ou roteiro negativo). Após a transcrição, as respostas foram tratadas individualmente de acordo com a pergunta para melhor organização dos pontos principais do estudo.

Já na etapa quantitativa com o consumidor, foi utilizada a plataforma de pesquisa Qualtrics, visto que é uma plataforma de pesquisa fácil e dinâmica para capturar, analisar e criar relatórios de pesquisa. $O$ aplicativo já codifica e tabula as respostas automaticamente, bem como gera ainda tabelas e gráficos padronizados que agilizam a análise dos resultados, sem reduzir a importância da sensibilidade do pesquisador nas conclusões e recomendações do estudo.

Assim, através das etapas acima, se tornou possível a análise das práticas de compra e sua influência no momento da compra, obtendo as informações necessárias sobre a motivação de compra dos produtos oficiais do RIR.

\subsection{Limitações do Método}

Alguns fatores podem ser limitadores do estudo que está sendo realizado.

Para a realização desse tipo de pesquisa, utilizaram-se dados primários que vieram a partir de entrevistas pessoais em profundidade. Esta técnica possui como principais limitações: a falta de motivação e impaciência do entrevistado, a inadequada compreensão do significado das perguntas, a influência exercida 
pelo aspecto pessoal do entrevistador sobre o entrevistado e a influência do caráter interpretativo do próprio entrevistador (Gil, 2008).

Outro fator a se considerar é que o entrevistado pode não ser completamente sincero em suas respostas do questionário, ou que responda de forma rápida sem estar atento às perguntas.Como alguns respondentes foram selecionados por acessibilidade na rede de amigos, é importante ressaltar a possibilidade de tendenciosidade nas respostas, já que as entrevistas e o questionário foram realizados com pessoas próximas ao pesquisador.Para evitar gerar respostas falsas, em todas as etapas se buscou a imparcialidade. 


\section{Apresentação e análise dos resultados}

Neste capítulo, será apresentado e discutido os principais resultados alcançados sobre o objetivo de estudo deste trabalho,

\subsection{Análise das entrevistas em profundidade}

Como dito anteriormente, a pesquisa contou com entrevistas em profundidade, realizadas através do roteiro semiestruturado apresentado no Anexo 1. As entrevistas foram realizadas com um grupo de 8 respondentes. As informações obtidas nesta etapa ajudaram a estruturar $o$ questionário quantitativo. A seleção de sujeitos considerou tantas pessoas que foram quanto pessoas que não foram ao Rock in Rio. Também poderiam ou não ter comprado algum produto relacionado ao evento. O grupo entrevistado foi composto por jovens entre 19 e 25 anos, pertencentes à classe $A$ e $B$.

Como apresentado no Anexo 2 - Transcrição das Entrevistas quando questionados se compraram algum produto relacionado ao evento, dentre as principais respostas obtidas tem-se: comprei para mim mesmo, comprei para ter uma lembrança do evento, comprei porque me identifico com o evento, comprei por influência de familiares ou amigos, comprei para presentear alguém. Essas respostas foram de extrema importância para que pudesse elaborar as perguntas do questionário.

Os respondentes que não foram ao Rock in Rio, apresentaram respostas como: não comprei porque é muito caro e não significava nada, não comprei porque não gosta de produtos promocionais de eventos, não comprei porque não tive tempo para ir nas lojas, não comprei porque o ingresso já estava muito caro. Porém, apesar de não terem comprado, eles apresentaram arrependimento de não poder ter comprado o produto. 


\subsection{Análise do questionário online}

\subsubsection{Frequência e compra do produto}

Para dar início ao questionário, o primeiro bloco de perguntas questionou aos entrevistados se já tinham ido à alguma edição do Rock in Rio e se compraram algum produto relacionado ao evento.

Através da primeira pergunta é possível observar, de maneira geral mais da metade dos respondentes foram em alguma edição do evento.

\section{Tabela 6 - Pessoas que foram ao Rock in Rio}

\begin{tabular}{|c|c|c|c|c|}
\hline \# & Resposta & Barra & Resposta & $\%$ \\
\hline 1 & Sim & 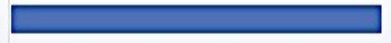 & 87 & $68 \%$ \\
\hline \multirow[t]{2}{*}{2} & Não & 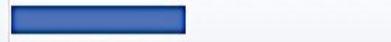 & 41 & $32 \%$ \\
\hline & Total & & 128 & $100 \%$ \\
\hline
\end{tabular}

Fonte: informações retiradas do resultado dos questionários feito com os consumidores

Através da Tabela 6, podemos perceber que dos 128 respondentes do questionário, 87 responderam que foram, e 41 respondentes responderam que não foram em alguma edição do Rock in Rio. Sendo assim, 68\% dos respondentes participaram de alguma edição do evento.

A segunda pergunta, foi feita para identificar os consumidores que foram ao evento e compraram algum tipo de produto, os consumidores que foram ao evento e não compraram, e os que não foram no evento, mas ainda sim compraram algum produto relacionado ao Rock in Rio.

Como mostra a Tabela 7, para as pessoas que foram no evento (87), menos da metade (41\%) comprou algum tipo de produto.

A Tabela 7 abaixo nos mostra também, que $59 \%$ das pessoas que foram ao evento e responderam o questionário não comprou nenhum produto oficial do RIR. 
Tabela 7 - Pessoas que foram ao evento e compraram ou não algum produto

\begin{tabular}{|l|l|l|r|r|}
\hline$\#$ & Resposta & Barra & Resposta & $\%$ \\
\hline 1 & Sim & & 36 & $41 \%$ \\
\hline 2 & Näo & & 51 & $59 \%$ \\
\hline & Total & & 87 & $100 \%$ \\
\hline
\end{tabular}

Fonte: informações retiradas do resultado dos questionários feito com os consumidores.

Já para as pessoas que não foram no evento (41), apenas 9 pessoas compraram algum produto do evento, representando apenas $22 \%$, como podemos perceber através dos resultados da Tabela 8.

Tabela 8 - Pessoas que não foram ao evento e compraram ou não algum produto

\begin{tabular}{|c|c|c|c|c|}
\hline \# & Resposta & Barra & Resposta & $\%$ \\
\hline 1 & Sim & $\square$ & 9 & $22 \%$ \\
\hline 2 & Näo & $\square$ & 32 & $78 \%$ \\
\hline & Total & & 41 & $100 \%$ \\
\hline
\end{tabular}

Fonte: informações retiradas do resultado dos questionários feito com os consumidores.

Estes números indicam que o foco principal deste grupo avaliado não está na compra dos produtos relacionados ao evento, e sim para o produto principal comprado por eles, os shows musicais do Rock in Rio.

Segundo (SHIMP, 2009), o objetivo de uma boa comunicação é impulsionar as pessoas para uma ação. Sendo assim, uma relação eficaz entre uma marca e seus consumidores, deve fazer muito mais do que apenas influenciar as atitudes e a conscientização do consumidor no sentido da marca. Essa relação exige um gasto de comunicação direcionado para o estímulo de algum desejo do consumidor. 


\subsubsection{Descrição do local de compra}

Perguntou-se aos respondentes onde estes compraram o produto do Rock in Rio. Como apresentado pelo Gráfico 1, obtendo-se como resposta que mais de $51 \%$ dos compradores obtiveram algum produto do evento através das lojas oficiais disponibilizadas dentro do próprio evento. Assim, demonstra que de alguma forma as lojas dentro do evento influenciam os consumidores para a compra de algum item relacionado ao evento.

Através do modelo de estímulo e resposta apresentado por (KOTLER, 200), os ambientes físicos, sociais, temporais, momentos passados, são características de consumo onde ocorrem influências que interferem diretamente no comportamento do consumidor.

\section{Gráfico 1 - Local de compra dos produtos do RIR}

Onde você comprou este produto?

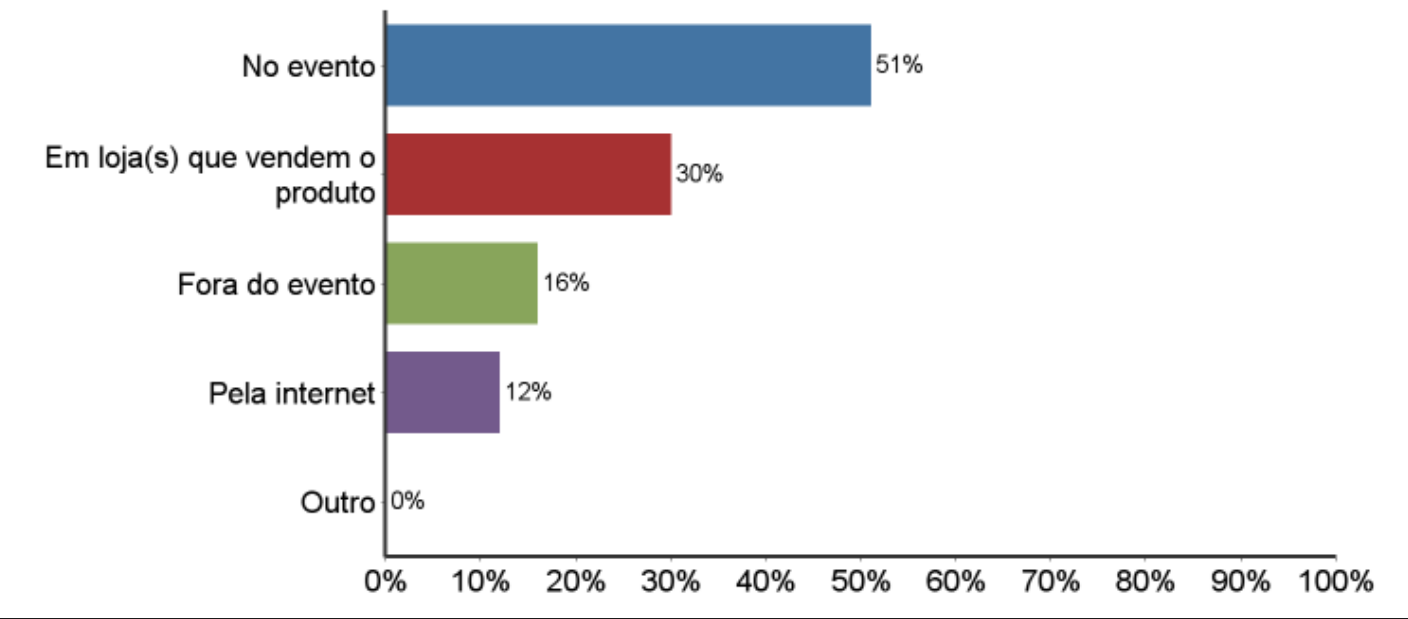

Fonte: informações retiradas do resultado dos questionários feito com os consumidores.

Observa-se, que $30 \%$ dos entrevistados adquiriram os produtos através das lojas parceiras do Rock in Rio, que disponibilizavam produtos do evento junto com os itens da loja. Essas lojas como Taco, Leader, Americanas, Submarino e outras, 
estão localizadas em diversos lugares e estão disponíveis para todo o tipo de público.

Um grupo de $16 \%$ dos entrevistados comprou fora do evento, ou seja, como a compra não foi realizada em uma loja oficial, o consumidor talvez não saiba se aquele produto que está comprando é original ou não. De acordo com o site G1, pessoas foram presas vendendo produtos falsificados com a marca do festival no entorno da Cidade do Rock, na Barra da Tijuca, Zona Oeste do Rio. De acordo com o MP, foram apreendidos 157 produtos falsificados com a marca Rock in Rio, entre chaveiros, camisetas, bandanas e copos. Na edição de 2013 do RIR foram apreendidos mais de três mil produtos no entorno da Cidade do Rock.

Outro ponto a se destacar é o baixo número de pessoas que compraram algum produto do evento pela internet, apenas $12 \%$ dos respondentes. Percebese então que os consumidores dos produtos oficiais do Rock in Rio têm preferência pela compra em lojas físicas.

\subsubsection{Produtos mais procurados}

O questionário também investigou os produtos mais comprados pelos consumidores, e o resultado pode ser visto na Tabela 9.

\section{Tabela 9 - Produtos mais comprados}


Quais os produtos que você comprou?

\begin{tabular}{|c|c|}
\hline Resposta & $\%$ \\
\hline Camisa T-shirts & $42 \%$ \\
\hline Camiseta & $30 \%$ \\
\hline Copo & $23 \%$ \\
\hline Capa de celular & $14 \%$ \\
\hline Boné & $12 \%$ \\
\hline Canga & $9 \%$ \\
\hline Caneca & $7 \%$ \\
\hline Outros & $5 \%$ \\
\hline Chaveiro & $5 \%$ \\
\hline Caneta & $5 \%$ \\
\hline Xícara & $2 \%$ \\
\hline Carro & $2 \%$ \\
\hline Bandana & $2 \%$ \\
\hline Lenço & $2 \%$ \\
\hline Imã & $2 \%$ \\
\hline Copo de Shot & $2 \%$ \\
\hline Jóias (cordão, pingente, outros) & $2 \%$ \\
\hline Sacochilabag & $2 \%$ \\
\hline Mochila & $2 \%$ \\
\hline Óculos & $2 \%$ \\
\hline Balde de geloice & $0 \%$ \\
\hline Luva de neopreme & $0 \%$ \\
\hline Babador & $0 \%$ \\
\hline Porta biscoito & $0 \%$ \\
\hline Calça jeans & $0 \%$ \\
\hline Almofada & $0 \%$ \\
\hline Biquini & $0 \%$ \\
\hline Ar condicionado & $0 \%$ \\
\hline Caixa de som & $0 \%$ \\
\hline Bolsa de neoprene & $0 \%$ \\
\hline Capa de notebook & $0 \%$ \\
\hline Capa de tablet & $0 \%$ \\
\hline Capa carregadora de celular & $0 \%$ \\
\hline Frigobarmini & $0 \%$ \\
\hline Power bank & $0 \%$ \\
\hline Headphone & $0 \%$ \\
\hline Sanduicheira & $0 \%$ \\
\hline Total & $100 \%$ \\
\hline
\end{tabular}

Fonte: informações retiradas do resultado dos questionários feito com os consumidores.

Nesse quesito, a camisa T-shirt e a camiseta tiveram o maior índice de respostas, representando, $42 \%$ e $30 \%$ respectivamente. De acordo com os organizadores do evento, as lojas de produtos oficiais do Rock in Rio comemoraram as boas vendas registradas. Segundo eles, o produto mais vendido é a camiseta oficial, sendo que pelo menos 8 mil camisetas oficiais da edição tenham sido vendidas em apenas um dia de show pelas lojas de produtos oficiais.

A pesquisa mostra também, que os copos e a capa de celular estão entre os itens mais procurados pelos respondentes. Os copos estão representaram 
uma parcela de $23 \%$ das respostas dos respondentes e a capa de celular $14 \%$ dos respondentes.

Outro número interessante é o número de compradores de boné, $12 \%$ dos respondentes. Segundo os organizadores, das filas que se formaram em volta dos balcões das lojas que vendem os produtos, os itens mais disputados são os bonés e as camisetas, nesta amostra, os copos e capas de celulares estão à frente dos bonés.

Segundo reportagem da Veja Rio, dos diversos produtos que foram postos à venda nas lojas oficiais da Cidade do Rock, alguns agradaram mais ao público que outros. Enquanto camisetas venderam como água no festival, alguns itens disponíveis nas seis lojas do espaço ficaram"encalhados".

Segundo Peter e Oslon (2010), o envolvimento com a marca gera no consumidor uma relação de afetividade e relevância com a marca e como resultado disso, gera a mesma relação com os produtos e serviços relacionados à mesma.

O mercado de entretenimento torna esses grandes eventos algo infinito na memória dos consumidores, os produtos são uma ferramenta que funciona como uma postergação do sucesso e a fidelidade com o mesmo.

Para os respondentes que foram no evento e não compraram nenhum produto, perguntamos se caso pudesse comprar algum produto relacionado ao evento, qual gostaria de ter, como mostra a tabela abaixo: 


\section{Tabela 10 - Produtos que gostariam de ter comprado}

Caso pudesse comprar algum produto relacionado ao evento, qual produto gostaria de ter?

\begin{tabular}{|c|c|}
\hline Resposta & $\%$ \\
\hline Camisa T-shirts & $47 \%$ \\
\hline Caneca & $40 \%$ \\
\hline Copo & $34 \%$ \\
\hline Copo de Shot & $30 \%$ \\
\hline Headphone & $21 \%$ \\
\hline Chaveiro & $19 \%$ \\
\hline Caixa de som & $17 \%$ \\
\hline Camiseta & $15 \%$ \\
\hline Boné & $13 \%$ \\
\hline Imã & $13 \%$ \\
\hline Capa carregadora de celular & $11 \%$ \\
\hline Calça jeans & $9 \%$ \\
\hline Mochila & $9 \%$ \\
\hline Óculos & $9 \%$ \\
\hline Jóias (cordão, pulseira, brinco, pingente, outros) & $9 \%$ \\
\hline Caneta & $6 \%$ \\
\hline Bandana & $6 \%$ \\
\hline Xícara & $6 \%$ \\
\hline Almofada & $6 \%$ \\
\hline Capa de tablet & $6 \%$ \\
\hline Canga & $4 \%$ \\
\hline Capa de celular & $4 \%$ \\
\hline Sanduicheira & $4 \%$ \\
\hline Capa de notebook & $4 \%$ \\
\hline Sacochilabag & $4 \%$ \\
\hline Outros & $2 \%$ \\
\hline Porta biscoito & $2 \%$ \\
\hline Lenço & $2 \%$ \\
\hline Balde de geloice & $2 \%$ \\
\hline Frigobarmini & $2 \%$ \\
\hline Power bank & $2 \%$ \\
\hline Bolsa de neoprene & $2 \%$ \\
\hline Carro & $0 \%$ \\
\hline Ar condicionado & $0 \%$ \\
\hline Luva de neopreme & $0 \%$ \\
\hline Babador & $0 \%$ \\
\hline Biquini & $0 \%$ \\
\hline Total & $100 \%$ \\
\hline
\end{tabular}

Fonte: informações retiradas do resultado dos questionários feito com os consumidores.

Essas pessoas responderam que apesar de não ter comprado nada, caso pudessem, comprariam em sua maioria a camiseta do evento. A camisa foi o item mais escolhido, com um percentual de $47 \%$. Assim como as pessoas que foram no evento, a camisa ocupa a mesma posição no ranking de produtos mais comprados e desejados pelas pessoas que foram no evento.

Outros itens que tiveram destaque para essa pergunta foram: caneca (40\%), copo (34\%), copo de shot $(30 \%)$, headphone $(21 \%)$ e chaveiro $(19 \%)$. 
Esses itens são diferentes dos respondidos pelas pessoas que compraram alguma coisa do evento, tal fator pode ser explicado pois essa pergunta está relacionada diretamente ao desejo do respondente.

\subsubsection{Motivação de compra}

A seguir vamos apresentar as análises feitas com base nas respostas obtidas pela aplicação dos questionários no que se trata dos fatores motivacionais dos consumidores. Segundo KOTLER (2000), um motivo ou impulso é uma necessidade que está pressionando suficientemente uma pessoa a agir, é uma força interna não observável que estimula e compele a uma resposta comportamental, fornecendo uma orientação específica para essa resposta.

Para melhor entendimento sobre o perfil e as atitudes dos consumidores, foi apresentada uma série de perguntas para analisar o grau de concordância e discordância, levando em consideração o motivo de compra dos consumidores, conforme apresentado na Tabela 11.

\section{Tabela 11 - Por que comprou o produto do RIR?}

\begin{tabular}{|c|c|c|c|c|c|c|c|}
\hline Porgunta & $\begin{array}{l}\text { Concordo } \\
\text { totalmento }\end{array}$ & Concordo & $\begin{array}{l}\text { Concordo } \\
\text { parcialmento }\end{array}$ & $\begin{array}{l}\text { Nem concordo nem } \\
\text { discordo }\end{array}$ & $\begin{array}{l}\text { Discordo } \\
\text { parcialmento }\end{array}$ & Discordo & $\begin{array}{l}\text { Discordo } \\
\text { totalmento }\end{array}$ \\
\hline Comprei para dar de presenta & $16.2 \%$ & $13.5 \%$ & $10.8 \%$ & $2.7 \%$ & $2.7 \%$ & $13.5 \%$ & $40.5 \%$ \\
\hline $\begin{array}{l}\text { Comprei para guardar de } \\
\text { recordaçalolembrança }\end{array}$ & $51.4 \%$ & $18.9 \%$ & $2.7 \%$ & , & , & $5.4 \%$ & $21.6 \%$ \\
\hline $\begin{array}{l}\text { Comprei porque me identifico como } \\
\text { evento }\end{array}$ & $32.4 \%$ & $18.9 \%$ & $8.1 \%$ & $21.6 \%$ & . & . & $18.9 \%$ \\
\hline Comprei porque gostai do produto & $51.4 \%$ & $21.6 \%$ & $10.8 \%$ & $8.1 \%$ & • & , & $8.1 \%$ \\
\hline Comprei para ufizar no dia a dia & $27.0 \%$ & $16.2 \%$ & $24.3 \%$ & $16.2 \%$ & $2.7 \%$ & $2.7 \%$ & $10.8 \%$ \\
\hline Comprei para entrar no clima do evento & $29.7 \%$ & $10.8 \%$ & $10.8 \%$ & $8.1 \%$ & $8.1 \%$ & $5.4 \%$ & $27.0 \%$ \\
\hline $\begin{array}{l}\text { Comprei por infuencia de familiares ou } \\
\text { amigos }\end{array}$ & $5.4 \%$ & , & $8.1 \%$ & $5.4 \%$ & $2.7 \%$ & $32.4 \%$ & $45.9 \%$ \\
\hline Comprei por impulso & $13.5 \%$ & $10.8 \%$ & $8.1 \%$ & $10.8 \%$ & $8.1 \%$ & $10.8 \%$ & $37.8 \%$ \\
\hline $\begin{array}{l}\text { Comprei porque ass vezes compro algo } \\
\text { para me sentif bem }\end{array}$ & $21.6 \%$ & $13.5 \%$ & $8.1 \%$ & $10.8 \%$ & $2.7 \%$ & $8.1 \%$ & $35.1 \%$ \\
\hline
\end{tabular}

Fonte: informações retiradas do resultado dos questionários feito com os consumidores. 


\section{Gráfico 2- Porque comprou o produto do RIR?}

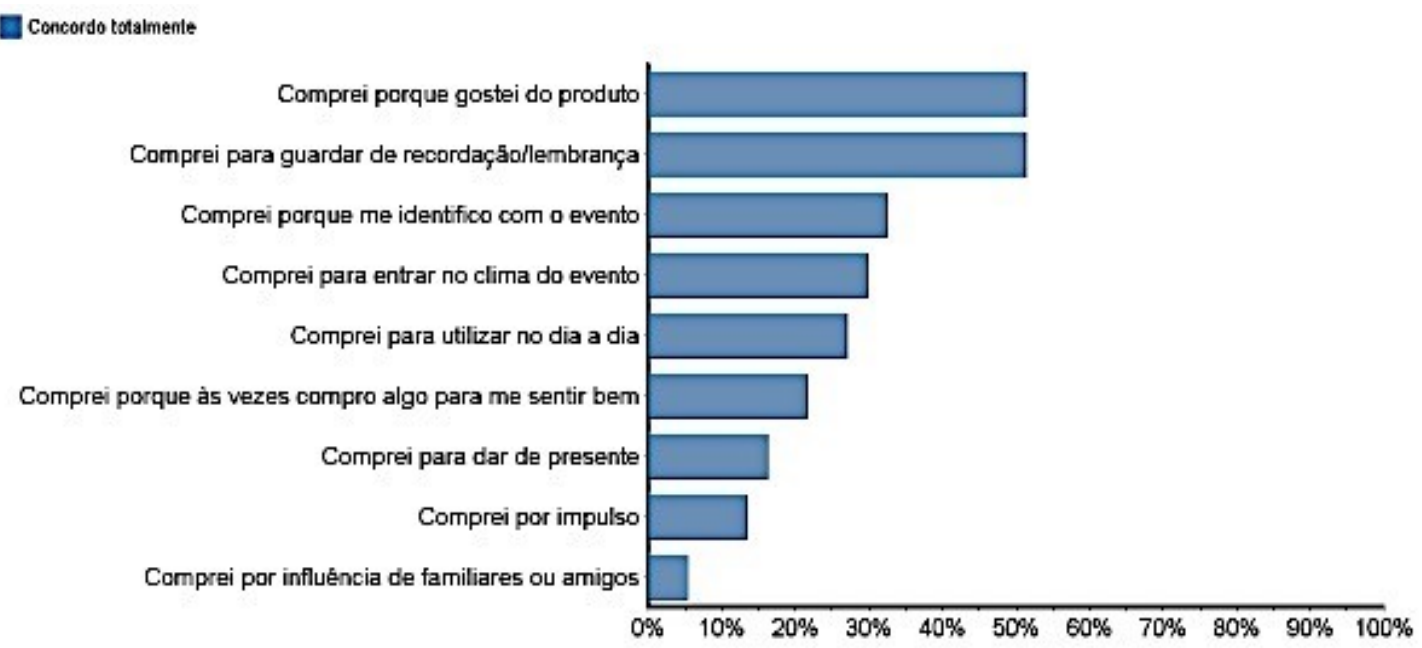

Fonte: informações retiradas do resultado dos questionários feito com os consumidores.

Conforme apresentado acima, as razões mais citadas foram: comprei para guardar de recordação/lembrança e comprei porque gostei do produto. Essas afirmações tiveram o percentual de concordância de 51,4\%, algo muito superior ao seu percentual de discordância que foi apenas de $21,6 \%$ e $8,1 \%$ respectivamente. Essas informações demostram que a principal motivação dos entrevistados é ter uma lembrança do evento para que se possa lembrar ou mostrar para outras pessoas que esteve no evento.

Outras afirmações relevantes foram: comprei porque me identifico com o evento e comprei para entrar no clima do evento, com um percentual de concordância de 32,4\% e 29,7\% respectivamente. Tal informação mostra que as pessoas compraram para satisfazer um desejo.

Para KOTLER (2000), os desejos são carências por satisfações específicas para atender às necessidades e são moldados pela cultura e pelas características pessoais.

A Tabela 12 analisa as razões dos respondentes que não compraram os produtos. As razões mais mencionadas foram: não comprei porque achei muito caro, não comprei porque gastei muito dinheiro, representando $51,1 \%$ e $19,1 \%$ respectivamente. 
Tabela 12 - Por que você não comprou?

\begin{tabular}{|c|c|c|c|c|c|c|c|}
\hline Porgunta & $\begin{array}{l}\text { Concordo } \\
\text { totalmento }\end{array}$ & Concordo & $\begin{array}{l}\text { Concordo } \\
\text { parcialmento }\end{array}$ & $\begin{array}{l}\text { Nom } \\
\text { concordo } \\
\text { nem } \\
\text { discordo }\end{array}$ & $\begin{array}{l}\text { Discordo } \\
\text { parcialmonto }\end{array}$ & Discordo & $\begin{array}{l}\text { Discordar } \\
\text { totalmente }\end{array}$ \\
\hline Não comprei porque achei muitb caro & $51.1 \%$ & $29.8 \%$ & $8.5 \%$ & $6.4 \%$ & $2.1 \%$ & • & $2.1 \%$ \\
\hline Não comprei porque não significa nada para mim & $14.9 \%$ & $12.8 \%$ & $23.4 \%$ & $19.1 \%$ & $12.8 \%$ & $17.0 \%$ & • \\
\hline Não comprei porque não tive tempo & . & $8.5 \%$ & $4.3 \%$ & $12.8 \%$ & $8.5 \%$ & $34.0 \%$ & $31.9 \%$ \\
\hline Não comprei porque gastei muitb dinheiro & $19.1 \%$ & $31.9 \%$ & $6.4 \%$ & $21.3 \%$ & $2.1 \%$ & $10.6 \%$ & $8.5 \%$ \\
\hline $\begin{array}{l}\text { Não comprei porque meus familiares ou amigos } \\
\text { me infuenciaram a nฐ̃o comprar }\end{array}$ & $2.1 \%$ & $4.3 \%$ & $4.3 \%$ & $19.1 \%$ & $2.1 \%$ & $31.9 \%$ & $36.2 \%$ \\
\hline Não comprei porque a loja estava muitb cheia & - & $17.0 \%$ & $19.1 \%$ & $23.4 \%$ & $10.6 \%$ & $14.9 \%$ & $14.9 \%$ \\
\hline $\begin{array}{l}\text { Não comprei porque não gostei da qualidade dos } \\
\text { produlos }\end{array}$ & . & $2.1 \%$ & $4.3 \%$ & $42.6 \%$ & $6.4 \%$ & $34.0 \%$ & $10.6 \%$ \\
\hline $\begin{array}{l}\text { Não comprei porque não gosto de usar produtos } \\
\text { com marcas ou logos de eventos }\end{array}$ & $10.6 \%$ & $6.4 \%$ & $19.1 \%$ & $14.9 \%$ & $12.8 \%$ & $23.4 \%$ & $12.8 \%$ \\
\hline $\begin{array}{l}\text { Não comprei porque não me identifico como } \\
\text { evento, apenas queria assisf̂r um determinado } \\
\text { show }\end{array}$ & $4.3 \%$ & $4.3 \%$ & $10.6 \%$ & $17.0 \%$ & $10.6 \%$ & $40.4 \%$ & $12.8 \%$ \\
\hline $\begin{array}{l}\text { Não comprei porque não tinha muita variedade } \\
\text { de produto na loja dentro do events }\end{array}$ & . & , & $2.1 \%$ & $42.6 \%$ & $12.8 \%$ & $21.3 \%$ & $21.3 \%$ \\
\hline
\end{tabular}

Fonte: informações retiradas do resultado dos questionários feito com os consumidores.

\section{Gráfico 3 - Por que não comprou?}

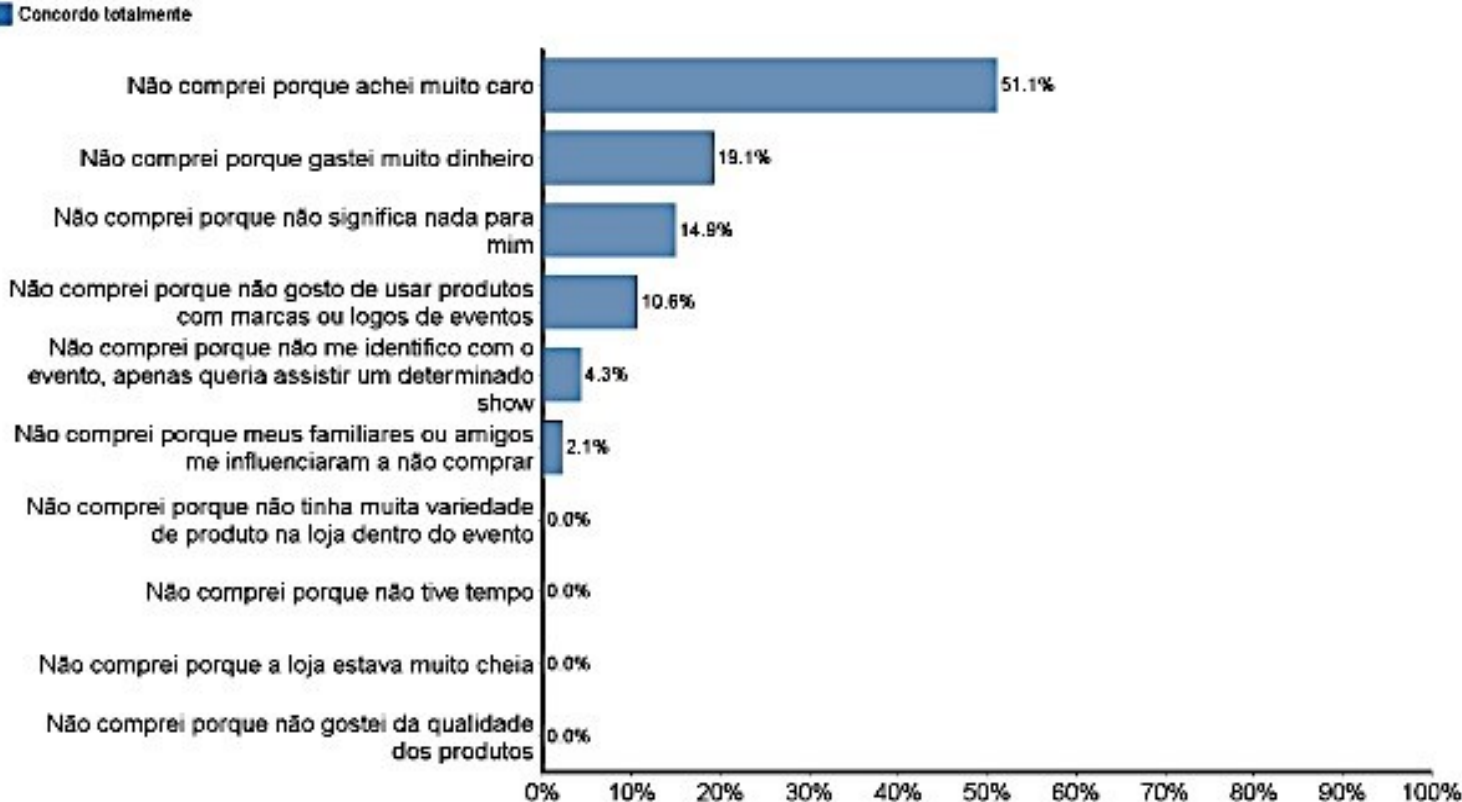

Fonte: informações retiradas do resultado dos questionários feito com os consumidores.

Com essas informações podemos perceber que a principal razão para que as pessoas não tenham comprado nada do evento foi o valor elevado dos produtos relacionados ao evento. Segundo reportagem do site Diário do Grande $A B C$, os preços de alguns itens podem chegar até $R \$ 180$. Um boné custava de $R \$ 70$ a $R \$ 90$, roupa de bebê $R \$ 60$ e as camisetas tradicionais $R \$ 80$.

Outro ponto que pode ser analisado levando em consideração a afirmação de que as pessoas não compraram porque gastaram muito dinheiro 
no evento, é devido ao elevado valor do ingresso e principalmente ao elevado valor da alimentação na Cidade do Rock. Segundo reportagem do site Veja Rio, depois de duas edições em três anos, cariocas e turistas já se acostumaram com o fato de que comer e beber no Rock in Rio não é algo barato. Tal fato pode ter sido um dos grandes motivos para que muitas pessoas tenham deixado de comprar algum produto do evento.

\subsubsection{Estímulos e influências no momento da compra}

O comportamento do consumidor pode ser influenciado por diversos fatores no momento da compra. Esses fatores podem ser culturais, sociais, pessoais e psicológicos. Nesta parte apresenta-se nos gráficos abaixo os resultados de duas perguntas relacionadas aos estímulos e influência no processo de compra do consumidor. Para isso, foi perguntado no questionário: se tinham a intenção de adquirir o produto/lembrança antes de entrar na loja e o que influenciou o desejo de comprar o produto. O resultado é apresentado no Gráfico 4.

\section{Gráfico 4 - Influência na compra}

O que gerou/influenciou o desejo de comprar o produto?

Concordo totalmente

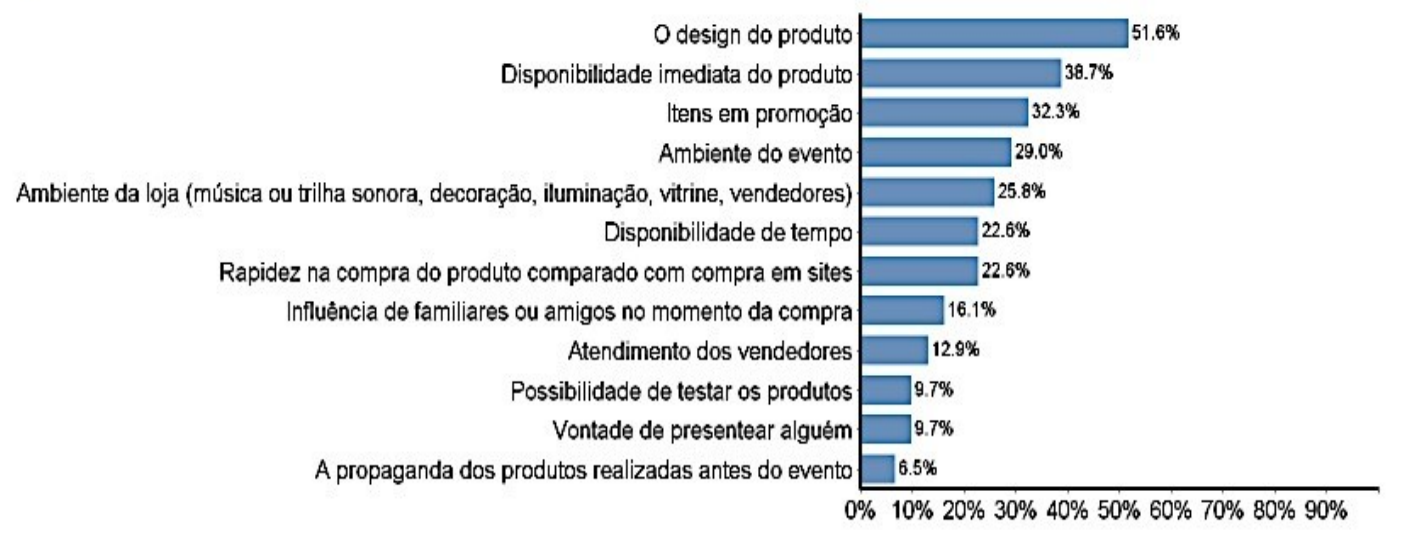

Fonte: informações retiradas do resultado dos questionários feito com os consumidores. 


\section{Gráfico 5 - Intenção de compra}

Você tinha a intenção de adquirir o produto/lembrança antes de entrar na loja?

Concordo totalmente

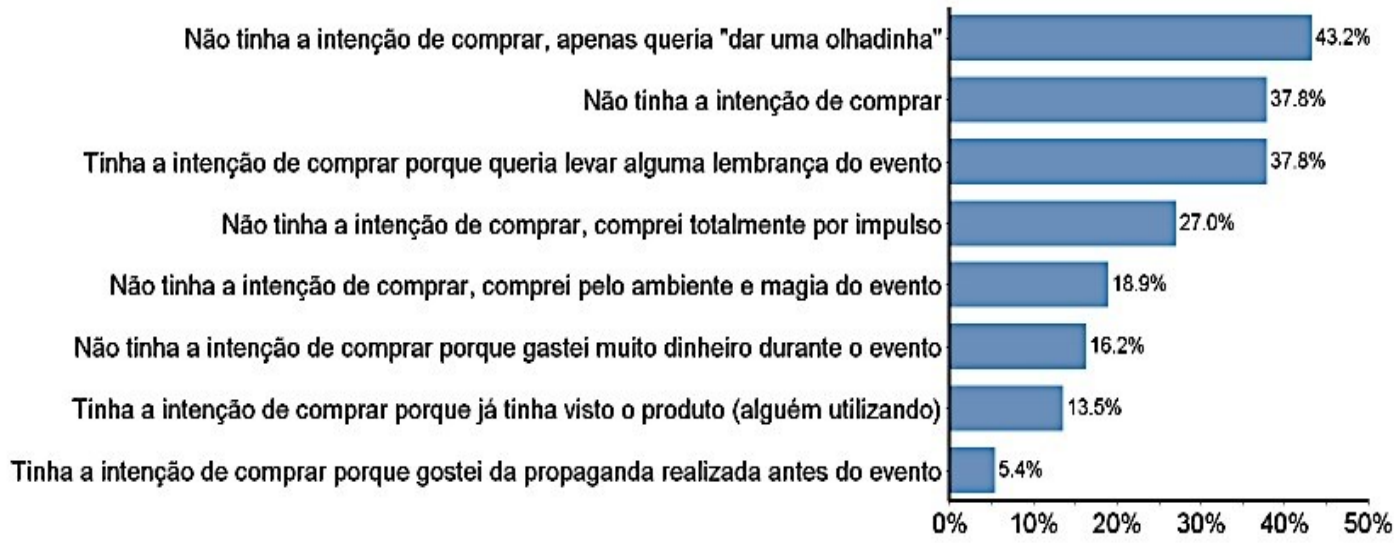

Fonte: informações retiradas do resultado dos questionários feito com os consumidores.

Através dos Gráficos 4 e 5 apresentados, percebe-se que a maioria dos respondentes não tinha a intenção de comprar nenhum produto. De acordo com os gráficos, $43,2 \%$ das pessoas não tinha a intenção de comprar, apenas queria dar uma olhadinha e $37,8 \%$ não tinha intenção alguma de comprar algum produto do evento. Outra afirmação relevante é a de que $37,8 \%$ das pessoas tinha a intenção de comprar porque queria levar alguma lembrança do evento.

Observando o Gráfico 4, a maioria respondeu que a compra foi influenciada principalmente pelo design do produto e pela disponibilidade imediata do produto. Tais respostas representaram respectivamente, 51,6\% e $38,7 \%$ das respostas. Conforme KOTLER (1998), existem quatro fatores psicológicos que influenciam as escolhas dos consumidores: motivação, percepção, aprendizagem e crenças e atitudes. Com isso, tais fatores foram representativos para a motivação de compra dos produtos do RIR pelos consumidores.

De acordo com Kotler, os estímulos ambientais de marketing têm a capacidade de entrar no consciente do comprador. Portanto, para se ter o entendimento do que acontece no consciente do consumidor, levando em conta o estímulo recebido externamente e a decisão final de compra faz com que seja de extrema importância as características e seus processos de decisão dos mesmos. Assim, outros fatores como itens em promoção, ambiente do evento e principalmente o ambiente das lojas, foram estímulos que influenciaram na compra dos consumidores, como mostrado no gráfico 4 . 
O ambiente da loja pode ser um grande motivador paras as compras não planejadas de produtos do evento. Estímulos do interior da loja como: disposição dos produtos na loja, sonorização, iluminação e arrumação das vitrines fez com que $25,8 \%$ dos responderes escolhessem essa afirmação.

Em determinadas situações ocorrem diversas influências que interferem de alguma forma no comportamento do consumidor. Os ambientes físicos e sociais, tempo, um momento passado, são as características principais de uma típica situação de consumo. 


\section{Conclusões e recomendações para novos estudos}

O Rock in Rio é reconhecido como um influente agente econômico, movimentando o mercado de eventos no país. Como exemplo disso, podemos perceber a enorme quantidade de produtos licenciados com a marca do evento. $\mathrm{Na}$ edição de setembro de 2015, que aconteceu na Cidade do Rock, Rio de Janeiro, foram licenciados 643 itens com a marca Rock In Rio, divididos em 76 categorias. Segundo os organizadores do evento, esses números são um recorde comparado à última edição do festival, quando atingiu uma marca de 600 produtos. Os produtos oficiais do festival vão de peças de vestuário a artigos de higiene, alimentação, beleza, automóveis, dentre outros.

Ao perceber que poderiam explorar mais o impacto e a repercussão de seu evento, seus organizadores passaram a comercializar produtos relacionados à marca. Estes produtos licenciados ou produtos derivados podem ser encontrados em diversas categorias e muitas vezes continuam sendo comercializados após o término do evento.

Com o intuito de fazer um estudo sobre o comportamento do consumidor e compreender as razões que os fazem realizar determinada compra, este estudo investigou o que motiva o consumidor a comprar os produtos oficiais da marca.

Para as empresas, a marca funciona como uma excelente forma de aprimorar seu valor e aumentar o seu reconhecimento. Uma empresa com um bom programa de marketing pode fazer com que suas marcas consigam entrar e se estabelecer em um mercado bastante competitivo onde se têm muitas que já são reconhecidas e respeitadas. Na compra de uma marca forte, o consumidor adquire, além dos produtos, todos os aspectos relacionados a ela, ou seja, adquire qualidade, emoção, satisfação, aventura, comodidade, conforto, dentre de uma série atributos da marca.

Entre os fatores que influenciam diretamente a decisão de compra e consumo estão os aspectos sociais, culturais, pessoais, psicológicos e também os 4P's de marketing. Com isso, foram apresentadas as teorias motivacionais de Freud, Maslow e Herzberg, bem como estímulos e necessidades.

Para atingir aos objetivos pretendidos realizou-se pesquisa bibliográfica, seguida de pesquisa exploratória e qualitativa e de uma terceira fase 
quantitativa. A pesquisa mostrou que menos da metade das pessoas que foram ao evento comprou algum tipo de produto, levando em consideração o período antes do evento e o período após o evento. Este fato indica que o foco principal dos consumidores entrevistados não está na compra dos produtos relacionados ao evento, e sim para o produto principal comprado por eles, os shows musicais do Rock in Rio.

Através do modelo de estímulo e resposta apresentado por (KOTLER, 200), os ambientes físicos, sociais, temporais, momentos passados, são características de consumo onde ocorrem influências que interferem diretamente no comportamento do consumidor. Percebeu-se que a maioria das pessoas que compraram algum produto, realizaram a compra dentro da Cidade do Rock, fator esse que pode ter sido influenciado pelo ambiente e estímulos dentro da loja.

A maioria dos entrevistados que compraram não tinha a intenção de comprar nenhum produto, a compra foi influenciada principalmente pelo design do produto e pela disponibilidade imediata do produto no momento da compra. Outros fatores como itens em promoção, ambiente do evento e principalmente o ambiente das lojas, foram estímulos influenciadores no momento da compra segundo a pesquisa.

Por fim, o que mais motivou as pessoas a comprarem o produto do evento foi a vontade de guardar uma recordação do evento e porque gostaram no produto. Essas informações demostram que o principal motivo da compra é a vontade de registrar aquele momento não só na memória, como também com algo físico de utilidade. Percebeu-se também que a grande maioria das pessoas foi desmotivada a comprar algum produto, devido aos altos preços dos mesmos ou por já terem gasto muito dinheiro com alimentação e ingresso do evento.

\subsection{Sugestões e recomendações para novos estudos}

Muitas são as pesquisas que podem surgir a partir desse estudo. Para aprofundar a discussão sobre o tema abordado, essa linha de estudo pode ser desenvolvida através de investigação ainda mais profunda, com outros eventos do mesmo porte do Rock in Rio. Outra linha de pesquisa poderia ser a comparação do mercado brasileiro de eventos com outros mercados no mundo.

Tentar entender o que leva um consumidor a se identificar com uma marca e relacionar isso com o processo de compra é um desafio que se apresenta aos pesquisadores, bem como comparar seus hábitos, preferências e investimentos nesses produtos. 


\section{Referências Bibliográficas}

AAKER, David. JOACHIMSTHALER, Erich. Como Construir Marcas Líderes. Porto Alegre: Bookman, 2007.

ABEOC BRASIL. ABEOC BRASIL E Sebrae lançam o mais completo levantamento sobre a indústria de eventos já realizado no país. Disponível em: <http://www.abeoc.org.br/2014/10/abeoc-brasil-e-sebrae-lancam-o-maiscompleto-levantamento-sobre-a-industria-de-eventos-ja-realizado-no-pais/> Acesso em 22/09/2015

ABEOC BRASIL. Associação Brasileira de Empresas de Eventos. Disponível em: <http://www.abeoc.org.br/tag/rock-in-rio/> Acesso em 18/09/2015.

ABEOC. Riotur divulga estudo sobre impacto do Rock in Rio na cidade Disponível em: <http://www.abeoc.org.br/2013/09/riotur-divulga-estudo-sobreimpacto-do-rock-in-rio-na-cidade/> Acesso em 18/09/2015.

ADMIISTRADORES. Licenciamento e estratégia de marcas. Disponível em: <http://www.administradores.com.br/artigos/marketing/licenciamento-eestrategia-de-marcas/20431/> Acesso em: 18/09/2015

ADMINISTRADORES. Atendimento diferenciado ao cliente. Disponível em: http://www.administradores.com.br/artigos/marketing/atendimento-diferenciadoao-cliente/59676/

Acesso em: 18/04/2016.

ADMINISTRAÇÃO E GESTÃO. Fatores que influenciam o processo de compra. Disponível em: <http://administracaoegestao.com.br/marketing- 
internacional/fatores-que-influenciam-o-processo-de-compra/>

Acesso em: 09/12/2015

ALMANAQUEVITUAL - CULTURA EM MOVIMENTO. Rock in Rio bate recorde e terá mais de 640 produtos licenciados em 2015. Disponível em:

$<$ http://almanaquevirtual.com.br/rock-in-rio-bate-recorde-e-tera-mais-de-640-

produtos-licenciados-em-2015/>

Acesso em: 10/12/2015

ANPAD. Associação Nacional de Pós-Graduação e Pesquisa em Administração http://www.anpad.org.br/ anpad/

ARMOSTRONG, G. KOTLER, P., Princípios de Marketing. 12. Ed. São Paulo: Person Prentice Hall, 2007. 600 p.

BERTUCCI,J. Metodologiabásica para elaboração de trabalhos de conclusão de cursos (TCC). São Paulo: Atlas, 2012.

CEDET. Marcas e Branding. Disponível em:

<http://www.cedet.com.br/index.php?/Tutoriais/Marketing/marcas-e-

branding.html>

Acesso em: 14/03/2016

CHEVRON, Jacques R. (1998) The Delphi Process: a strategic branding methodology. Jounal of Consumer Marketing Bingley: Emerald Insight. ISSN 0736-3761.

CHIZZOTTI, A. (2006). Pesquisa em ciências humanas e sociais (8a ed.). São Paulo: Cortez.

COBRA, Marcos (organizador). Marketing do entretenimento. São Paulo, SP: Editora Senac, 2008.

COLBERT, F. Marketing for the Culture anda the Arts. Montreal: HEC, 2012.

DEOLHONOMERCADO. O show não pode parar: mercado de entretenimento está otimista. Disponível em: < http://www.deolhonomercado.com.br/economia/o- 
show-nao-pode-parar-mercado-de-entretenimento-esta-otimista/> Acesso em: 15/12/2015

DIALNET. Comportamento do consumidor para aquisição de produtos licenciados de personagens infantis: um estudo qualitativo. Disponível em: $<$ https://www.google.com.br/url?sa=t\&rct=j\&q=\&esrc=s\&source=web\&cd=2\&ved= OahUKEwj2wl_PjY_NAhVM4yYKHQJKDcUQFggkMAE\&url=https\%3A\%2F\%2Fdi alnet.unirioja.es\%2Fdescarga\%2Farticulo\%2F5061356.pdf\&usg=AFQjCNGUNB pEle9_RBDNg-x983cXbyN-pg\&sig2=zJveVOt0Scjl5SAWwq7cOg> Acesso em: 20/04/2016.

ESPORTE.GOV. Legados de Megaeventos. Disponível em: < http://www.esporte.gov.br/arquivos/ascom/publicacoes/Legados\%20de\%20Mega eventos\%20Esportivos_Portugus_e_Ingls.pdf> Acesso em: 06/03/2016

ESTGV. Necessidades, motivações e desejos. Disponível em: $<$ https://www.google.com.br/url?sa=t\&rct=j\&q=\&esrc=s\&source=web\&cd=1\&ved= 0ahUKEwi16YHI5oTNAhUGMSYKHTLADLkQFggdMAA\&url=http\%3A\%2F\%2Fw ww.estgv.ipv.pt\%2FPaginasPessoais\%2Fcseabra\%2Fdocs\%2FCOMPORTAME NTO\%2520DO\%2520CONSUMIDOR\%2520TURISMO\%2FAulas\%2FPonto\%25 $2011 \% 2520-\% 25201.1 \% 2520$

\%2520Necessidades\%2C\%2520motiva\%25E7\%25F5es\%2520e\%2520desejos \%2Fponto\%2520II.1.1.ppt\&usg=AFQjCNFCN7c7Ym6SkxDxvSV5VtxR5XKcw\&sig2=hBaki91Vswvst4thQ8Udbw> Acesso em: 05/03/2016

Faria, Marina. MARKETING CULTURAL: O IMPACTO DA PROMOÇÃO DE EVENTOS DE MÚSICA NA IMAGEM COORPORATIVA. Perspec. Contemp., Campo Mourão, v.6, n.1, p. 18-44, jan./jun. 2011.

FOLHA DE S.PAULO. Novo consumidor: mais informado, mais exigente, mais consciente. Disponível em:

$<$ http://www1.folha.uol.com.br/topofmind/2014/10/1528719-novo-consumidormais-informado-mais-exigente-mais-consciente.shtml>

Acesso em: 04/03/2016 
FREUD, S. O ego e o id. ESB, Rio de Janeiro: Imago, 1980. v. XIX.

G1. Venda de produtos falsos do Rock in Rio leva quatro pessoas à prisão. Disponível em: <http://g1.globo.com/musica/rock-inrio/2015/noticia/2015/09/venda-de-produtos-falsos-do-rock-rio-leva-quatropessoas-prisao.html> Acesso em: 20/04/2016

GIL, Antônio Carlos. Como elaborar projetos de pesquisa. São Paulo: Atlas, 2002.

GIL, Antônio Carlos. Como elaborar projetos de pesquisa. São Paulo: Atlas, 2010.

GIL, Antônio Carlos. Como elaborar projetos de pesquisa. São Paulo: Atlas, 1996.

GUIMARÃES, L.B. de M. Funções de um Produto, Tendências Formais e Éticas de Consumo.In:

Guimarães, L.B. de M (ed.) Ergonomia de Produto, v.2: Porto Alegre: FEENG, 1999.

GUIMARÃES, L.B. de M. Funções de um Produto, Tendências Formais e Éticas de Consumo.In: Guimarães, L.B. de M (ed.) Ergonomia de Produto, v.2: Porto Alegre: FEENG, 1999.

KOTLER, P; KELLER, K. L..Administração de Marketing. 12. ed. São Paulo: Pearson Prentice-Hall, 2006.

KOTLER, P. Administração de marketing: a edição do novo milênio. São Paulo: Prentice Hall, 2000.

KOTLER, P. Definição da estratégia de produto. Administração de marketing. São Paulo: Pearson/Prentice Hall, 2000. 
KOTLER, Philip - Administração de Marketing. Editora Prentice Hall. São Paulo, 2004. P.427

KOTLER, Philip; KELLER, Kevin L. Administração de marketing.12.ed.SãoPaulo:

KOTLER, Philip. Marketing para o Século XXI, São Paulo: Ediouro, 2009.

LICENSING Brasil. Licenciamento, um atalho para o bom negócio. Nㅜ 29. Ano 6, maio/junho de 2012.

LICENSING Brasil. Licensing Expo 2012: Quem poderá nos surpreender. № 30. Ano 6, julho/agosto de 2012.

LICENSING Brasil. Mercado Brasileiro de licenças: o que falta em informação sobre em potencial. N³1. Ano 6, setembro/outubro de 2012.

LOVELOCK, C; WRIGHT, L. O serviço do ponto de vista do cliente. Serviços: marketing e gestão. São Paulo: Saraiva, 2001.

MAGALHÃES, Távira. Valor da marca para o consumidor: Um estudo Empírico no Setor Automotivo. Universidade FUMEC, 2006.

MEIO\&MENSAGEM. Disponível em:< http://www.meioemensagem.com.br/home/marketing/noticias/2015/09/28/Rockin-Rio-os-patrocinadores-de-2017.html>. Acesoo em 27/09/2015.

MEIO\&MENSAGEM. Rock in Rio: recorde de licenciamento. Disponível em: <http://www.meioemensagem.com.br/home/marketing/2015/06/17/rock-in-riorecorde-no-licenciamento.html> Acesso em: 20/10/2015.

MELO NETO, F. P. de. Marketing de eventos. 2. ed. Rio de Janeiro: Sprint, 1999. MINTZBERG, H.; AHLSTRAND, B.; LAMPEL, J. Safari de estratégia. Porto 'Alegre: Bookman, 2000.

MinC. Ministério da Cultura do Brasil - http://www.cultura.gov.br/ 
MONOGRAFIASBRASILESCOLA. Comportamento do consumidor. Disponível em: <http://monografias.brasilescola.uol.com.br/administracaofinancas/comportamento-consumidor-comparativo-dos-fatores-escolha.htm> Acesso em: 02/03/2016.

MONOGRAFIASBRASILESCOLA. Processo de decisão de compra e estratégias de publicidade. Disponível em: < http://monografias.brasilescola.uol.com.br/administracao-financas/processodecisao-compra-estrategias-publicidade.htm > Acesso em: 23/04/2016.

MOTTA, Fernando C. Prestes; VASCONCELOS, Isabella, F. Gouveia de. Teoria geral da administração. 3. ed. São Paulo: Pioneira, 2006.

MOVIMENTO. , Porto Alegre, v. 15, n. 02, p. 211-231, abril/junho de 2009. Entretenimento: uma mercadoria com valor em alta. Disponível em: <http://www.seer.ufrgs.br/Movimento/article/viewFile/3055/5144> Acesso: 18/05/2016

NEALE, S; SMITH, M. Contemporary Hollywood Cinema.New York: Routledge, 2013.

NETO, Manoel Marcondes Machado; Marketing Cultural: das práticas à teoria. Rio de Janeiro: Editora Ciência Moderna Ltda, 2002.

OSTA, Ivan Freitas da. Marketing cultural - O patrocínio de atividades culturais como ferramenta de construção de marca. São Paulo: Atlas, 2004.

Pearson Prentice Hall, 2006.

PETER, J.; OLSON, J. Comportamento do Consumidor e Estratégias de Marketing. São Paulo: McGraw Hill Brasil, 2010. 
PORTAL EDUCAÇÃO. Marketing cultural e associação de marcas. Disponível em: <http://www1.portaleducacao.com.br/marketing/artigos/55188/marketingcultural-e-associacao-de-marcas $>$

Acesso em: 20/04/2016

PRODUCAO. Necessidades e desejos. Disponível em:

<http://www.producao.ufrgs.br/arquivos/publicacoes/104_necessidades $\% 20$ e $\% 2$ Odesejos.pdf>

Acesso em: 05/11/2015

PWC. Mercado de entretenimento e mídia brasileiro chegará a US\$ 71 bilhões em 2017, segundo projeção da PwC. São Paulo, 2013 Disponível em:<http://www.pwc.com.br/pt/sala-de-imprensa/assets/press-release/release14th-global-entertainment-media-outlook-2013-2017-06-13.pdf>.

Acesso em: 25/09/2015.

RESENHANDO. Cidade do Rock estáprontaparareceber o Rock in Rio 2015. Disponívelem<http://www.resenhando.com/2015/09/cidade-do-rock-esta-prontapara-receber.html>

Acessoem: 20/04/2016.

REVISTA ESPACIOS. The determination of the characteristics on the student's preference in the choice of a private institution of higher learning.Disponivel em: <http://www.revistaespacios.com/a13v34n05/13340505.html> Acesso em: 08/04/2016

ROCKINRIO. FAQ - Sobre o Rock in Rio. Disponível em:

http://rockinrio.com/rio/ingressos/ingressos-rock-in-rio-brasil/faq-ingressos/ Acesso em: 02/10/2015.

Acesso em: 02/04/2016.

ROCKINRIO. Release produtos licenciados. Disponível em: $<$ https://rockinrio.com/rio/wp-content/uploads/sites/12/2015/06/Release-produtoslicenciados.pdf>

Acesso em: 22/09/2015. 
ROCKINRIO. Rock in Rio bate recorde e terá mais de 640 produtos licenciados em 2015. Disponível em: < https://rockinrio.com/rio/wpcontent/uploads/sites/12/2015/06/Release-produtos-licenciados.pdf > Acesso em: 20/05/2016.

SEBRAE. Economia Criativa - Mercado de entretenimento chegará a US\$ 71 bilhões em 2017. São Paulo, 2013. Disponível em:

<http://www.sebrae2014.com.br/Sebrae2014/Alertas/Mercado-deentretenimento-chegar\%C3\%A1-a-US\$-71-bilh\%C3\%B5es-em2017\#.U3Kq9PIdVIR>.

Acesso em: 25/09/2014.

SEBRAE. Entenda o comportamento dos consumidores. Disponível em: $<$ http://www.sebrae.com.br/sites/PortalSebrae/artigos/entenda-o-comportamentodos-consumidores,4c73ce6326c0a410VgnVCM1000003b74010aRCRD > Acesso em: 18/05/2016.

SOLOMON, M.R. Comportamento do consumidor: comprando, possuindo e sendo. $5^{\text {a }}$ ed. São Paulo: Prentice Hall, 2002.

SOLOMON, Michael R. O Comportamento do Consumidor - Comprando, possuindo e sendo. Porto Alegre: Bookman, 2011.

SOUZA, Antonio Carlos de; FIALHO, FanciscoAntonio Pereira; OTANI, Nilo. TCC: métodos e técnicas. Florianópolis: Visaual Books, 2007.

TRINDADE, Eneus. Merchandising televisivo: tie-in. In: PEREZ, Clotilde; BARBOSA, Ivan Santo, Org(s). Hiperpublicidade: fundamentos e interfaces. São Paulo: Thompson Learning, 2007.

TURISMO. Plano Nacional de turismo 2013-2016. Disponível em: < http://www.turismo.gov.br/sites/default/turismo/o_ministerio/plano_nacional/downl oads_plano_nacional/PNT_11_09_2012.pdf>Acesso em:

TURNER, G. Cinema Como Prática Social. Tradução de Mauro Silva. São Paulo: Summus, 1997. 
VERGARA, Sylvia Constant. Métodos de pesquisa em administração. São Paulo: Atlas, 2005. 287 p. ISBN 852243963X. 


\section{Anexo 1 - Roteiro das Entrevistas em Profundidade}

Perguntas filtro:

- Já foi em alguma edição do Rock in Rio?

- Você comprou alguma lembrança/produto do evento?

\section{$\underline{\text { Caso Afirmativo }}$}

1. Onde comprou?

2. Por que comprou?

3. Comprou durante o evento? (pode ter sido antes ou depois)

4. Quais os produtos que você comprou? (Independente de onde comprou, loja ou não )

5. Qual a diferença em comprar na loja oficial do evento?

6. Quando você comprou o produto no evento, você tinha a intençãode adquirir antes de entrar nessa loja?

7. O que gerou/influenciou o desejo de comprar o produto?

8. Comprou para você mesmo?

9. Comprou para dar de presente? Para quem?

10. Alguém te influenciou na compra?

11. Você se arrepende de ter comprado algum produto relacionado ao evento? Por quê?

\section{Caso Negativo:}

1. Por que não comprou?

2. Você se arrepende de não ter comprado algum produto relacionado ao evento? Por quê?

3. Caso pudesse comprar algum produto relacionado ao evento, qual produto gostaria de ter? 


\section{Anexo 2 - Transcrição das Entrevistas em Profundidade}

\section{Entrevista 1}

Perguntas filtro:

A: Olá, estou realizando algumas entrevistas para minha monografia, que tem como tema o Rock in Rio. Vou fazer algumas perguntas para que possamos conversar um pouco sobre, tudo bem?

B: Claro, vamos lá... espero poder ajudar.

A: Vou começar realizando uma pergunta bem direta: Você já foi em alguma edição do Rock in Rio?

B: Sim, fui em 2013 no dia do show do Bon Jovi que sou muito fã.

A: E você comprou alguma coisa do Rock in Rio? Alguma lembrança?

B: Eu comprei uma capinha de celular na época, que uso até hoje.

Caso Afirmativo

A: Você se lembra onde comprou?

B: Comprei em uma das lojas dentro do evento.

A: Por que você comprou?

B: Ah ... comprei mesmo pra ser uma recordação ... uma lembrança daquele momento com meus amigos. Além de ser algo que já coloquei no celular.

A: Você falou que comprou uma capinha para seu celular, e na hora em que você comprou, sentiu alguma diferença em comprar na loja oficial do evento?

$B$ : Acho que pela atmosfera do evento e pelo ambiente da loja, me fez ter mais vontade de comprar alguma coisa. Acho que por você estar lá na hora, dentro da atmosfera, na transição de um show e outro, acaba influenciando em lembrar daquele momento de alguma forma.

A: Quando você comprou o produto no evento, você tinha a intenção de adquirir antes de entrar nessa loja?

B: Eu entrei na loja só para ver os produtos, dar uma olhadinha (risadas) . Não tinha intenção nenhuma de comprar alguma coisa porque já tinha gastado bastante dinheiro com comida e bebida lá dentro. Só que acabei me deixando levar pelo momento mesmo. 
A: Esse deixar levar pelo momento, você acha que foi o que gerou ou influenciou o seu desejo de comprar o produto?

B: Acho que pode sim, e também porque o porque era um item necessário para mim. O design da capinha também me chamou atenção. Acho que também por todos os meus amigos (três amigos que estavam comigo), terem comprado alguma coisa, então eu também não queria ficar de fora (risadas).

A: Você acha então que seus amigos te influenciaram na compra?

B: Ah, acho que sim, como eu falei, todo mundo comprou né. Então resolvi meio que unir a vontade de comprar alguma coisa, com algo que eu estava precisando.

A: Você se arrepende de ter comprado algum produto relacionado ao evento? Por quê?

B: Claro que não, porque foi uma coisa que eu utilizei e utilizo até hoje. $E$ as vezes quando troco a capa do meu celular e olho para ela, me faz lembrar dos momentos e daquele dia no Rock in Rio.

\section{Entrevista 2}

Perguntas filtro:

A: Já foi em alguma edição do Rock in Rio?

B: Já, já fui, adoro o Rock in Rio . Em 2011 eu fui a três dias ... Quer que fale quais? Vou falar. Um dia era Kate Perry com a Rihanna, acho que tinha o Elton John no meio, muito ruim odiei. Ai, o outro dia, foi da Shakira (muito top), acho que tinha Ivete também. Algum dos dias também tinha NXO e foi muito legal também porque eles estavam super animados de estar lá. O outro dia foi muito top também.

Ai em 2013 eu fui em dois dias, minha memoria é péssima. Foi no show da Beyoncé, horroroso o show dela, mas o David Guetta foi muito bom, valeu a pena mesmo sendo com pen drive ou sem pen drive. No outro dia que eu fui foi bem legal também que foi o niclabck e o Bon Jovi,

Em 2015 eu fui no dia do Sam Smith com o Lulu Santos e Rihanna. Tá foi isso.

A: Você comprou alguma lembrança/produto do evento?

B: Comprei, comprei, eu comprei um bonezinho muito lindo floral do Rock in Rio , muito lindo, foi só nessa ultima de 2015 mesmo, que eu só fui em um dia e então dava pra gastar mais dinheiro. 


\section{A: Onde comprou esse produto?}

B: Ah, em uma lojinha lá que estava vendendo lá dentro do Rock in Rio mesmo. Em uma das lojinhas.

A: Por que você comprou o boné, por que você resolveu comprar?

$B$ : Ah porque eu amo o Rock in Rio, tem tudo haver comigo. $E$ o boné era muito fofo, então ... tipo ...ele era um boné lindo de um evento que eu amo, então eu comprei.

A: Então você comprou durante o evento? (pode ter sido antes ou depois)

B: Foi durante o evento.

A: Quais os produtos que você comprou, foi apenas o boné?

B: Sim, comprei só o boné mesmo.

A: Qual a diferença em comprar na loja oficial do evento? (Explorar essa resposta)

B: Ah porque teve toda uma experiência entendeu, porque tipo ... eu lá experimentando o boné e o clima do evento, as músicas.

A: Quando você comprou o produto no evento, você tinha a intenção de adquirir antes de entrar nessa loja?

B: Não foi totalmente por impulso, eu olhei, vi esse boné, achei lindo, combinou e comprei.

A: O que gerou/influenciou o desejo de comprar o produto?

$B$ : Eu tenho uma amiga, que achou ele lindo também, mas ela tava meio assim de comprar. E ela não quis comprar então comprei eu mesmo.

A: Você comprou para você mesmo então né?

B: Pra mim mesmo.

A: Comprou alguma coisa para dar de presente? Para quem?

B: Não, não comprei.

A: Então você acha que foi sua amiga que te influenciou?

B: Isso mesmo acho que ela teve uma grande parcela de culpa.

A: Você se arrepende de ter comprado algum produto relacionado ao evento? Por quê?

B: Não, cloro que não. Ele é lindo, fica decorando o meu quarto. Eu não uso boné que não fica muito bem em mim, então uso mesmo pra decoração.

\section{Entrevista 3}

Perguntas filtro:

A: Já foi em alguma edição do Rock in Rio? 
B: Já, em 2013 e em 2015.

A: Você comprou alguma lembrança/produto do evento?

B: Em 2013 eu comprei uma paleta e em 2015 eu comprei uma boné.

\section{Caso Afirmativo}

A: Onde comprou?

B: No Rock in Rio querido, na lojinha oficial de lá de dentro.

A: Por que comprou?

B: Qual dos dois?

A: Ou melhor, por que você comprou a paleta?

B: A paleta eu comprei porque eu fazia aniversario de namoro no dia que eu fui no show com o meu amor. Ai ele tocou uma musica muito romântica pra mim com o violão dele.

A: E por que você comprou o boné?

B: Porque eu já tinha terminado com ele ai .... Mentira, eu comprei o boné porque era muito bonito mesmo. Eu ja tinha visto o boné assim que eles lançaram, porque eles lançam primeiro no site então eu ja estava determinada em comprar aquele boné porque ele é muito lindo.

A: Comprou durante o evento mesmo né? (pode ter sido antes ou depois)

B: Foi, foi durante o evento. Eu fui em dois dias em 2015 e tipo assim, foi a primeira coisa que eu comprei em 2015 porque eu estava com medo de que acabasse..

A: Os produtos que você comprou então foram o boné e a paleta? (Independente de onde comprou, loja ou não )

B: Isso, só essas duas coisas.

A: Qual a diferença em comprar na loja oficial do evento? (Explorar essa resposta)

B: Cara, é tipo, você confirmar que foi sabe? Você comprar em uma taco qualquer um compra, agora lá dentro é super diferente. Primeiro poque eu não tinha visto que tinham em outros lugares, então os produtos que eu queria realmente só tinham lá e foi primeira coisa que eu quis fazer. Eu entrei no evento e quis comprar pra ter uma lembrança daquele momento pra minha vida toda.

A: Quando você comprou o produto no evento, você tinha a intenção de adquirir antes de entrar nessa loja?

B: Entao, eles lancaram primeiro no facebook, eu sigo o face do rock in rio, e eles lançaram os produtos que eles iam vender. Entaom, desde que eu vi o boné 
eu estava apaixonada , fiquei contanto as horas para chegar no Rock in Rio e comprar o boné.

A: O que gerou/influenciou o desejo de comprar o produto?

$B$ : A foi a propaganda que fizeram antes.

A: Você achou a propaganda bem feita?

B: Não foi nem a propaganda em si, porque foi um post simples. Foi mesmo a qualidade, estética do boné e qualidade que eu imaginei ser pelo preço.

A: Comprou para você mesmo?

B: Foi, o boné foi para mim e a paleta foi para o meu namorado.

A: Comprou para dar de presente? Para quem?

B: Comprei a paleta pra dar de presente pro meu namorado.

A: Alguém te influenciou na compra?

B: Não, foi um desejo meu. Tanto presentear o meu namorado como comprar o boné pra mim.

A: Você se arrepende de ter comprado algum produto relacionado ao evento? Por quê?

B: Aham, a paleta. Meu namorado terminou comigo, gastei dinheiro com aquele idiota. O boné apesar de eu nunca usar porque eu fico igual o bozo eu não me arrependo porque eu adoro.

\section{Entrevista 4}

Perguntas filtro:

A: Já foi em alguma edição do Rock in Rio?

B: Já fui, em 2013 só em um dia.

A: Você comprou alguma lembrança/produto do evento?

B: Comprei sim, algumas lembranças.

Caso Afirmativo

A: Onde comprou?

B: Eu comprei lá dentro mesmo, na loja deles.

A: Por que comprou?

B: Eu comprei porque logo depois do rock in rio eu iria visitar minha tia e minhas primas que moram em New York a 13 anos, então eu quis comprar algumas coisas pra elas de lembrança mesmo.

A: Comprou durante o evento mesmo né? (pode ter sido antes ou depois) 
B: Isso.

A: Os produtos que você comprou? (Independente de onde comprou, loja ou não)

B: Eu comprei camisa e uns cordões de guitarra do Rock in Rio pras minhas primas.

A: Qual a diferença em comprar na loja oficial do evento? (Explorar essa resposta)

B: Acho que no meu caso foi por facilidade mesmo, porque eu já estava lá dentro e como eu cheguei cedo tive tempo de visitar todos os lugares de lá de dentro.

A: Quando você comprou o produto no evento, você tinha a intenção de adquirir antes de entrar nessa loja?

B: Já sim, eu fui com isso na cabeça, pensando na viagem que eu iria fazer no final do ano.

A: O que gerou/influenciou o desejo de comprar o produto?

B: Vontade de presentear minha família.

A: Comprou para você mesmo?

B: Não comprei nada para mim, só para outras pessoas mesmo.

A: Comprou para dar de presente? Para quem?

B: Então, como eu falei eu comprei pra dar de lembrança para minha tia e minha primas que moram a muitos anos fora do Brasil e que fazem muita falta quando a gente vai em um evento desses com a família.

A: Alguém te influenciou na compra?

B: Não, eu e minha irmã que tivemos a ideia de comprar mesmo.

A: Você se arrepende de ter comprado algum produto relacionado ao evento? Por quê?

B: Também não. Eu nunca me arrependo de presentar alguém, independente da situação.

\section{Entrevista 5}

Perguntas filtro:

A: Já foi em alguma edição do Rock in Rio?

B: Já sim, fui em todas as edições.

A: Você comprou alguma lembrança/produto do evento?

B: Sim, sempre compro. 


\section{Caso Afirmativo}

A: Onde comprou?

B: Eu comprei fora do evento mesmo em uma loja que vendia os produtos oficiais, nessas lojas de roupa mesmo.

A: Por que comprou?

B: Comprei para usar nos três dias que eu fui assistir show.

A: Comprou durante o evento? (pode ter sido antes ou depois)

B: Não, comprei antes do evento mesmo, para poder usar durante o evento.

A: Os produtos que você comprou? (Independente de onde comprou loja ou não)

B: Comprei 3 camisas, para poder customizar, fazer regata e tal e ir com um look diferente para os dias que eu fui.

A: Qual a diferença em comprar na loja oficial do evento? (Explorar essa resposta)

B: Eu acho que comprar lá dentro é legal, mas eu sempre tive a visão de que os produtos dentro do evento são mais caros. Eu não sei se é verdade, porque não comparei as camisas que eu comprei com as que tinham lá na loja.

A: Quando você comprou o produto no evento, você tinha a intenção de adquirir antes de entrar nessa loja?

B: Eu comprei antes do evento mesmo, então eu tinha a intenção sim de comprar.

A: O que gerou/influenciou o desejo de comprar o produto?

$B$ : Vontade de criar um visual meu com uma roupa do evento.

A: Comprou para você mesmo?

B: Comprei pra usar lá.

A: Comprou alguma coisa para dar de presente? Para quem?

$B$ : Não comprei nada pra ninguém.

A: Alguém te influenciou na compra?

B: Não, eu mesmo que quis.

A: Você se arrepende de ter comprado algum produto relacionado ao evento? Por quê?

B: Não me arrependo. 


\section{Entrevista 6}

Perguntas filtro:

A: Já foi em alguma edição do Rock in Rio?

B: Já fui, eu fui em 2013.

A: Você comprou alguma lembrança/produto do evento?

B: Não mesmo. Detalhe, eu vi que estavam vendendo, sei lá, lama no pote! Quem compra isso meu Deus?

Caso Negativo:

A: Por que não comprou?

B: Porque é muito caro e não significa nada pra mim.

A: Você se arrepende de não ter comprado algum produto relacionado ao evento? Por quê?

B: Não. Por que eu compraria?

A: Porque você não compraria?

B: Porque eu não gosto dessas coisas promocionais e também não gosto de gastar dinheiro com essa coisas. Tá, vou comprar camiseta escrita Rock in Rio só se for para usar na academia mesmo.

A: Caso pudesse comprar algum produto relacionado ao evento, qual produto gostaria de ter?

B: Eu nem sei os produtos que eles vendem pra falar a verdade. Se fosse de graça eu pegaria é claro. Mas acho que compraria uma canga, na verdade acho que não. De repente compraria uma capinha de celular porque essa minha aqui está estragada.

\section{Entrevista 7}

Perguntas filtro:

A: Já foi em alguma edição do Rock in Rio?

B: Eu fui na ultima edição, no show da Rihanna e do Sam Smith, foi incrível.

A: Você comprou alguma lembrança/produto do evento?

B: Vontade eu tive de comprar, mas acabou que que eu não tive tempo pra falar a verdade. Eu cheguei cedo pra pegar um lugar de frente pro palco pra assistir o show da Rihanna de perto porque eu sou muito fã. 


\section{Caso Negativo:}

A: Por que não comprou?

B: Como eu falei, como nessa edição eu tinha como prioridade assistir só o show da Rihanna, então eu não tive tempo pra ficar passeando pelo evento pra poder comprar alguma coisa.

A: Você se arrepende de não ter comprado algum produto relacionado ao evento? Por quê?

B: Ah, eu me arrependo sim, não sei nem se posso falar que é arrependimento, mas eu acho que se tivesse ido em alguma loja lá dentro eu acabaria comprando alguma coisa.

A: Caso pudesse comprar algum produto relacionado ao evento, qual produto gostaria de ter?

B: Acho que compraria uma toalha daquelas tipo canga sabe? Acho que poderia usar depois pra ir pra praia e também em outros festivais.

\section{Entrevista 8}

Perguntas filtro:

A: Já foi em alguma edição do Rock in Rio?

B: Fui sim, em duas edições.

A: Você comprou alguma lembrança/produto do evento?

B: Não.

Caso Negativo:

A: Por que não comprou?

B: Porque o ingresso já estava muito caro.

A: Você se arrepende de não ter comprado algum produto relacionado ao evento? Por quê?

B: Sim, porque o boné estava muito bonito mas estava muito caro. Acho que estava custando quase noventa reais o boné, sem condições de gastar esse dinheiro.

A: Caso pudesse comprar algum produto relacionado ao evento, qual produto gostaria de ter?

$\mathrm{B}$ : O boné, porque ele é bonito. Apenas por comprar mesmo, porque geralmente boné não cabe na minha cabeça 


\section{Anexo 3 - Questionário sobre compra de produtos do Rock in Rio.}

Perguntas Filtro

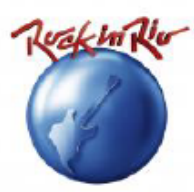

PESQUISA SOBRE COMPRA DE PRODUTOS DO

ROCK IN RIO

Gostariamos de contar com a sua colaboração nesta pesquisa.

A pesquisa é um estudo sobre o comportamento do consumidor que faz parte de uma dissertação de Monografia do IAG/PUC-Rio. O objetivo é identificar a motivação de compra do consumidor dos produtos do Rock in Rio. Sua participaçáo será muito importante Peço que responda com atençäo e sinceridade.

Suas respostas não serão analisadas individualmente, mas sim juntamente às de outras pessoas; além disso, não possuirão identificação.

Você já foi a alguma edição do Rock in Rio?

Sim

Näo

Você comprou algum produto relacionada(o) ao evento?

Sim

Näㅇ

Você comprou algum produto relacionada(o) ao evento?

S Sim

Nä๋

\section{ROTEIRO POSITIVO}

Onde você comprou esta produto?

$\square$ No evento

$\checkmark$ Fora do evento

$\checkmark$ Pela internet

Em loja(s) que vendem o produto com o nome da marca

Outro

Quais os produtos que você comprou? 


\begin{tabular}{|c|c|c|c|c|}
\hline Camisa T-shirts & $\square$ Caneta & $\square$ Caneca & $\square$ Headphone & $\square \operatorname{lmã}$ \\
\hline Camiseta & Chaveiro & $\square$ Xicara & Power bank & Babador \\
\hline$\square$ Calça jeans & $\begin{array}{l}\square \text { Jóias (cordão, } \\
\text { pingente, outros) }\end{array}$ & $\square$ Copo de Shot & Frigobarmini & Porta biscoito \\
\hline$\square$ Boné & $\square$ Capa de tablet & Bolsa de neoprene & $\square$ Ar condicionado & $\square$ Carro \\
\hline$\square$ Biquini & $\square$ Capa de notebook & $\square$ Caixa de som & $\square$ Almofada & $\square$ Lenço \\
\hline$\square$ Canga & $\square$ Óculos & $\square$ Capa de celular & $\square$ Luva de neopreme & $\square$ Bandana \\
\hline Sacochilabag & $\square$ Sanduicheira & $\begin{array}{l}\text { Capa carregadora de } \\
\text { œelular }\end{array}$ & $\square$ Balde de geloice & $\square$ Outros \\
\hline Mochila & $\square$ Copo & & & \\
\hline
\end{tabular}

A seguir, será apresentada uma série de perguntas e possíveis respostas relativas às atividades de compras. Para cada uma delas, gostaríamos que você apontasse seu grau de DISCORDÂNCIA ou de CONCORDÂNCIA.

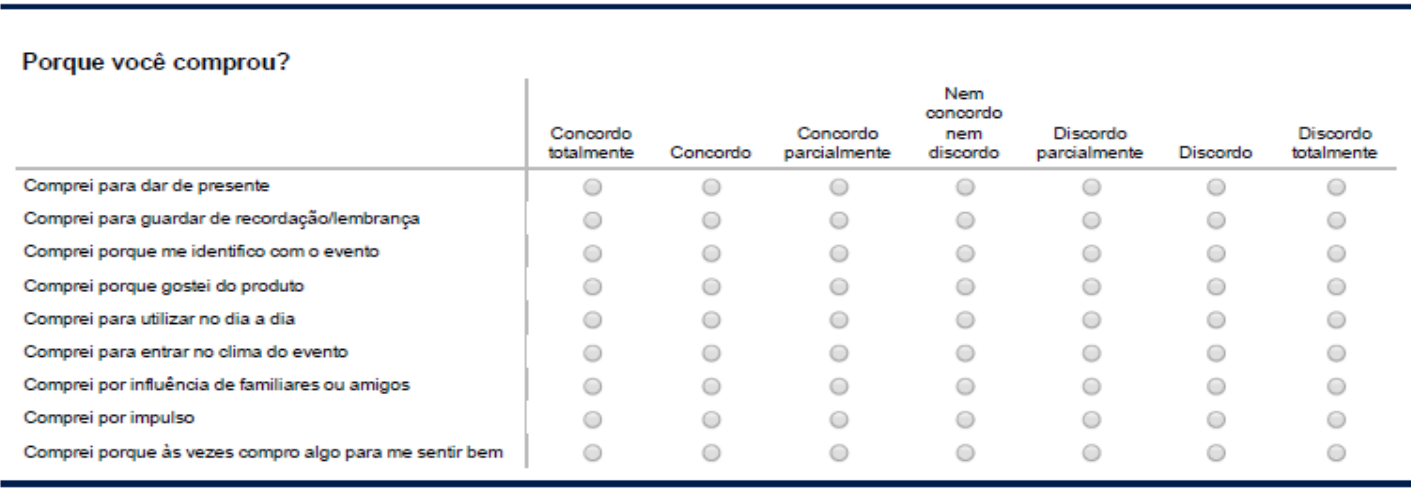

Você tinha a intenção de adquirir o produto/lembrança antes de entrar na loja?

\begin{tabular}{|c|c|c|c|c|c|c|c|}
\hline & $\begin{array}{l}\text { Concordo } \\
\text { totalmente }\end{array}$ & Concordo & $\begin{array}{l}\text { Concordo } \\
\text { parcialmente }\end{array}$ & $\begin{array}{c}\text { Nem } \\
\text { concordo } \\
\text { nem } \\
\text { discordo }\end{array}$ & $\begin{array}{l}\text { Discordo } \\
\text { parcialmente }\end{array}$ & Discordo & $\begin{array}{l}\text { Discordo } \\
\text { totalmente }\end{array}$ \\
\hline Não tinha a intenção de comprar & 0 & 0 & 0 & 0 & 0 & 0 & 0 \\
\hline $\begin{array}{l}\text { Não tinha a intenção de comprar, apenas queria "dar uma } \\
\text { olhadinha" }\end{array}$ & 0 & 0 & 0 & 0 & 0 & 0 & 0 \\
\hline $\begin{array}{l}\text { Não tinha a intenção de comprar porque gastei muito } \\
\text { dinheiro durante o evento }\end{array}$ & 0 & 0 & 0 & 0 & 0 & 0 & 0 \\
\hline $\begin{array}{l}\text { Não tinha a intenção de comprar, comprei pelo ambiente e } \\
\text { magia do evento }\end{array}$ & 0 & 0 & 0 & 0 & 0 & 0 & 0 \\
\hline $\begin{array}{l}\text { Näo tinha a intenção de comprar, comprei totalmente por } \\
\text { impulso }\end{array}$ & 0 & 0 & 0 & 0 & 0 & 0 & 0 \\
\hline $\begin{array}{l}\text { Tinha a intenção de comprar porque gostei da propaganda } \\
\text { realizada antes do evento }\end{array}$ & 0 & 0 & 0 & 0 & 0 & 0 & 0 \\
\hline $\begin{array}{l}\text { Tinha a intenção de comprar porque já tinha visto o } \\
\text { produto (alguém utilizando) }\end{array}$ & 0 & 0 & 0 & 0 & 0 & 0 & 0 \\
\hline $\begin{array}{l}\text { Tinha a intenção de comprar porque queria levar alguma } \\
\text { lembrança do evento }\end{array}$ & 0 & 0 & 0 & 0 & 0 & 0 & 0 \\
\hline
\end{tabular}

O que gerou/influenciou o desejo de comprar o produto?

\begin{tabular}{|c|c|c|c|c|c|c|c|}
\hline & $\begin{array}{l}\text { Concordo } \\
\text { totalmente }\end{array}$ & Concordo & $\begin{array}{l}\text { Concordo } \\
\text { parcialmente }\end{array}$ & $\begin{array}{l}\text { Nem } \\
\text { concordo } \\
\text { nem } \\
\text { discordo }\end{array}$ & $\begin{array}{l}\text { Discordo } \\
\text { parcialmente }\end{array}$ & Discordo & $\begin{array}{c}\text { Discordo } \\
\text { totalmente }\end{array}$ \\
\hline Odesign do produto & 0 & 0 & 0 & 0 & 0 & 0 & 0 \\
\hline Influência de familiares ou amigos no momento da compra & 0 & 0 & 0 & 0 & 0 & 0 & 0 \\
\hline thens em promoção & ○ & $\bigcirc$ & ○ & $\bigcirc$ & $\bigcirc$ & O & $\bigcirc$ \\
\hline Rapidez na compra do produto comparado com compra em sites & ○ & $\bigcirc$ & 0 & 0 & 0 & 0 & 0 \\
\hline Disponibilidade imediata do produto & O & ○ & 0 & ○ & O & $\bigcirc$ & $\bigcirc$ \\
\hline Disponibilidade de tempo & 0 & 0 & 0 & 0 & 0 & 0 & 0 \\
\hline Ambiente do evento & 0 & 0 & 0 & 0 & 0 & 0 & 0 \\
\hline \multicolumn{8}{|l|}{ Ambiente da loja (música ou trilha sonora, decoração, iluminação, } \\
\hline vitine, vendedores) & $\bigcirc$ & $\bigcirc$ & $\bigcirc$ & $\bigcirc$ & $\bigcirc$ & O & $\bigcirc$ \\
\hline Atendimento dos vendedores & ○ & ○ & 0 & O & O & 0 & 0 \\
\hline Possibilidade de testar os produtos & ○ & $\bigcirc$ & $\bigcirc$ & 0 & 0 & 0 & 0 \\
\hline A propaganda dos produtos realizadas antes do evento & O & $\bigcirc$ & O & $\bigcirc$ & 0 & $\bigcirc$ & $\bigcirc$ \\
\hline Vontade de presentear alguém & $\bigcirc$ & 0 & 0 & 0 & 0 & 0 & 0 \\
\hline
\end{tabular}


Você se arrepende de ter comprado algum produto relacionado ao evento?

\begin{tabular}{|c|c|c|c|c|c|c|c|}
\hline & $\begin{array}{l}\text { Concordo } \\
\text { totalmente }\end{array}$ & Concordo & $\begin{array}{l}\text { Concordo } \\
\text { parcialmente }\end{array}$ & $\begin{array}{l}\text { Nem } \\
\text { concordo } \\
\text { nem } \\
\text { discordo }\end{array}$ & $\begin{array}{l}\text { Discordo } \\
\text { parcialmente }\end{array}$ & Discordo & $\begin{array}{l}\text { Discordar } \\
\text { totalmente }\end{array}$ \\
\hline Não me arrependo de ter comprado & 0 & 0 & 0 & 0 & 0 & 0 & 0 \\
\hline Não me arrependo de ter comprado pois é algo que utilizo & 0 & ○ & ○ & ○ & O & O & ○ \\
\hline $\begin{array}{l}\text { Não me arrependo de ter comprado porque me faz ter uma boa } \\
\text { lembrança }\end{array}$ & O & ○ & O & ○ & O & O & ○ \\
\hline Não me arrependo de ter comprado pois acho o produto bonito & 0 & 0 & ○ & O & O & O & ○ \\
\hline $\begin{array}{l}\text { Não me arrependo de ter comprado pois gosto de presentear as } \\
\text { pessoas }\end{array}$ & $\bigcirc$ & O & O & ○ & O & O & O \\
\hline Eu me arrependo de ter comprado & 0 & 0 & 0 & 0 & 0 & 0 & 0 \\
\hline $\begin{array}{l}\text { Eu me arrependo de ter comprado porque a qualidade do produto } \\
\text { näo era a esperada }\end{array}$ & O & 0 & O & ○ & O & O & ○ \\
\hline Eu me arrependo de ter comprado porque gastei muito dinheiro & 0 & 0 & O & 0 & 0 & 0 & 0 \\
\hline Eu me arrependo de ter comprado porque nunca usei o produto & O & 0 & O & ○ & O & O & ○ \\
\hline $\begin{array}{l}\text { Eu me arrependo de ter comprado porque năo me traz boas } \\
\text { lembranças }\end{array}$ & 0 & 0 & 0 & ○ & ○ & ○ & O \\
\hline
\end{tabular}

\section{Roteiro Negativo}

A seguir, será apresentada uma série de perguntas e possíveis respostas relativas às atividades de compras. Para cada uma delas, gostaríamos que você apontasse seu grau de DISCORDÂNCIA ou de CONCORDÂNCIA.

Por que você não comprou?

\begin{tabular}{|c|c|c|c|c|c|c|c|}
\hline & $\begin{array}{l}\text { Concordo } \\
\text { totalmente }\end{array}$ & Concordo & $\begin{array}{l}\text { Concordo } \\
\text { parcialmente }\end{array}$ & $\begin{array}{l}\text { Nem } \\
\text { concordo } \\
\text { nem } \\
\text { discordo }\end{array}$ & $\begin{array}{l}\text { Discordo } \\
\text { parcialmente }\end{array}$ & Discordo & $\begin{array}{c}\text { Discordar } \\
\text { totalmente }\end{array}$ \\
\hline Não comprei porque achei muito caro & 0 & 0 & 0 & 0 & 0 & 0 & 0 \\
\hline Não comprei porque não significa nada para mim & O & ○ & 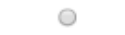 & 0 & O & $\bigcirc$ & $\bigcirc$ \\
\hline Näo comprei porque não tive tempo & 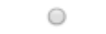 & 0 & 0 & O & O & ○ & $\bigcirc$ \\
\hline Näo comprei porque gastei muito dinheiro & O & ○ & ○ & 0 & O & ○ & ○ \\
\hline $\begin{array}{l}\text { Näo comprei porque meus familiares ou amigos me } \\
\text { influenciaram a nä̀ comprar }\end{array}$ & O & ○ & O & O & O & O & ○ \\
\hline Não comprei porque a loja estava muito cheia & O & ○ & 0 & O & O & O & O \\
\hline Não comprei porque não gostei da qualidade dos produtos & O & 0 & 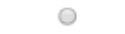 & 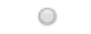 & O & O & O \\
\hline $\begin{array}{l}\text { Não comprei porque não gosto de usar produtos com } \\
\text { marcas ou logos de eventos }\end{array}$ & O & O & 0 & O & O & O & 0 \\
\hline $\begin{array}{l}\text { Näo comprei porque não me identifico com o evento. } \\
\text { apenas queria assistir um determinado show }\end{array}$ & O & O & O & O & O & O & 0 \\
\hline $\begin{array}{l}\text { Não comprei porque não tinha muita variedade de produto } \\
\text { na loja dentro do evento }\end{array}$ & 0 & $\bigcirc$ & O & $\odot$ & O & O & 0 \\
\hline
\end{tabular}

Você se arrepende de não ter comprado algum produto relacionado ao evento?

\begin{tabular}{|c|c|c|c|c|c|c|c|}
\hline & $\begin{array}{l}\text { Concordo } \\
\text { totalmente }\end{array}$ & Concordo & $\begin{array}{l}\text { Concordo } \\
\text { parcialmente }\end{array}$ & $\begin{array}{l}\text { Nem } \\
\text { concordo } \\
\text { nem } \\
\text { discordar }\end{array}$ & $\begin{array}{l}\text { Discordo } \\
\text { parcialmente }\end{array}$ & Discordo & $\begin{array}{l}\text { Discordar } \\
\text { totalmente }\end{array}$ \\
\hline Não me arrependo & ○ & $\bigcirc$ & ○ & $\bigcirc$ & O & ○ & ○ \\
\hline Não me arrependo porque não gosto de gastar dinheiro & ○ & 0 & O & 0 & $\bigcirc$ & O & 0 \\
\hline $\begin{array}{l}\text { Não me arrependo porque não gosto de produtos } \\
\text { promocionais }\end{array}$ & $\bigcirc$ & $\bigcirc$ & $\bigcirc$ & $\bigcirc$ & 0 & 0 & O \\
\hline Não me arrependo porque não usaria o produto & ○ & ○ & O & $\bigcirc$ & $\odot$ & $\bigcirc$ & ○ \\
\hline Eu me arrependo & ○ & ○ & ○ & ○ & $\bigcirc$ & $\bigcirc$ & $\bigcirc$ \\
\hline Eu me arrependo porque näo tive tempo & ○ & $\bigcirc$ & $\bigcirc$ & $\bigcirc$ & 0 & 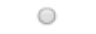 & $\bigcirc$ \\
\hline Eu arrependo porque os produtos estavam muito bonitos & $\bigcirc$ & $\bigcirc$ & 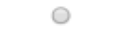 & ○ & 0 & 0 & 0 \\
\hline Eu me arrependo porque fui influenciado a näo comprar & 0 & 0 & 0 & 0 & 0 & 0 & 0 \\
\hline Eu me arrependo porque não tinha dinheiro & 0 & 0 & 0 & 0 & 0 & 0 & 0 \\
\hline
\end{tabular}


Caso pudesse comprar algum produto relacionado ao evento, qual produto gostaria de ter?

\begin{tabular}{|c|c|c|c|c|}
\hline 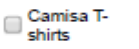 & $\square$ Caneta & $\square$ Caneca & $\square$ Headphone & Imã \\
\hline Camiseta & Chaveiro & $\square$ Xicara & Power bank & Babador \\
\hline$\square$ Calça jeans & $\begin{array}{c}\text { Jóias } \\
\text { (cordão, } \\
\square \text { pulseira, } \\
\text { brinco. } \\
\text { pingente, } \\
\text { outros) }\end{array}$ & 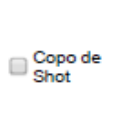 & $\square$ Frigobarmini & $\square$ Porta biscoito \\
\hline Boné & $\square_{\text {tablet }}^{\text {Capa de }}$ & $\square \begin{array}{l}\text { Bolsa de } \\
\text { neoprene }\end{array}$ & $\square \underset{\infty}{\text { Ar }}$ & Carro \\
\hline Biquini & $\square \begin{array}{c}\text { Capa de } \\
\text { notebook }\end{array}$ & $\square \begin{array}{l}\text { Caixa de } \\
\text { som }\end{array}$ & Almofada & $\square$ Lenço \\
\hline$\square$ Canga & $\square$ óculos & $\square \begin{array}{l}\text { Capa de } \\
\text { celular }\end{array}$ & $\begin{array}{l}\text { Luva de } \\
\text { neopreme }\end{array}$ & Bandana \\
\hline Sacochilabag & Sanduiche: & $\begin{array}{l}\text { Capa } \\
\text { carregadora } \\
\text { de celular }\end{array}$ & $\square \begin{array}{l}\text { Balde de } \\
\text { geloice }\end{array}$ & Outros \\
\hline Mochila & $D$ Copo & & & \\
\hline
\end{tabular}

Dados Demográficos2

QUESTÕ̃ES DEMOGRÁFICAS/CARACTERIZAÇÃO DO RESPONDENTE

Sexo:

Masculino

Feminino

Faixa etária:

até 18

de 18 a 25 anos

de 25 a 35 anos

de 35 a 45 anos

acima de 45 anos

\title{
Escolaridade:
}
Ensino Fundamental - Incompleto
Ensino Fundamental - Completo
Ensino Médio - Incompleto
Ensino Médio - Completo
Ensino Superior - Incompleto
Ensino Superior - Completo
Pós-graduação - Incompleto
- Pós-graduação - Completo

\author{
Estado Civil: \\ Solteiro \\ - Em um relacionamento \\ Casado \\ O Divorciado \\ Viúvo(a)
}

Qual a sua renda familiar mensal?

Até RS $1.576,00$

De R\$1.576,01 a R\$3.152,00

De R\$3.152,01 a R\$7.880.00

De R\$7.880,01 a R\$15.760,00

R\$15.760,01 ou mais 